IZA DP No. 5320

The Impact of the Crisis on Employment and the Role of Labour Market Institutions

Werner Eichhorst

Verónica Escudero

Paul Marx

Steven Tobin

November 2010 


\title{
The Impact of the Crisis on Employment and the Role of Labour Market Institutions
}

\author{
Werner Eichhorst \\ IZA
}

Verónica Escudero

IILS

Paul Marx

$I Z A$

Steven Tobin

IILS

Discussion Paper No. 5320
November 2010

IZA

P.O. Box 7240

53072 Bonn

Germany

Phone: +49-228-3894-0

Fax: +49-228-3894-180

E-mail: iza@iza.org

Any opinions expressed here are those of the author(s) and not those of IZA. Research published in this series may include views on policy, but the institute itself takes no institutional policy positions.

The Institute for the Study of Labor (IZA) in Bonn is a local and virtual international research center and a place of communication between science, politics and business. IZA is an independent nonprofit organization supported by Deutsche Post Foundation. The center is associated with the University of Bonn and offers a stimulating research environment through its international network, workshops and conferences, data service, project support, research visits and doctoral program. IZA engages in (i) original and internationally competitive research in all fields of labor economics, (ii) development of policy concepts, and (iii) dissemination of research results and concepts to the interested public.

IZA Discussion Papers often represent preliminary work and are circulated to encourage discussion. Citation of such a paper should account for its provisional character. A revised version may be available directly from the author. 
IZA Discussion Paper No. 5320

November 2010

\section{ABSTRACT \\ The Impact of the Crisis on Employment and the Role of Labour Market Institutions}

The paper takes a comparative perspective on the labour market impact on G20 and EU countries of the financial and economic crisis that began in 2008. It starts from the observation that the decline in employment and rise in unemployment in relation to output or GDP reductions varies significantly across countries. It examines the impacts from an institutional perspective taking into account different channels of external, internal and wage flexibility determined by both the institutional arrangements in place before the crisis and discretionary reforms implemented during the crisis. Emphasis is placed on the role of permanent and temporary jobs, working time adjustment, wage flexibility and active and passive labour market policies. The paper shows that, at least for the time being, unemployment increases have been contained in countries with comparatively strong internal flexibility. At the same time, however, it appears that the crisis has - at least in some cases contributed to a further dualization of labour markets given that risks are allocated unequally across types of employment.

JEL Classification: J58, J65, J21

Keywords: crisis, employment, EPL, institutions, flexibility, dual labour markets

Corresponding author:

Werner Eichhorst

IZA

P.O. Box 7240

53072 Bonn

Germany

E-mail: eichhorst@iza.org 


\section{Table of Contents}

Preface

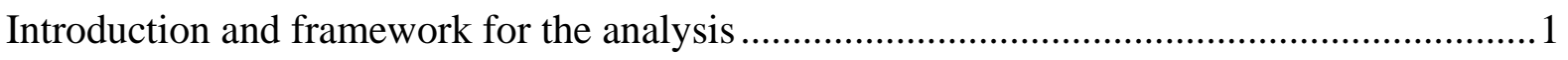

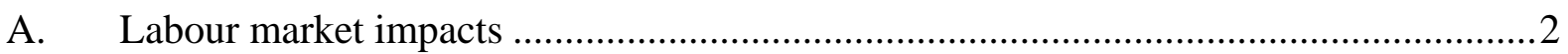

B. Factors influencing the labour market impacts of the crisis ......................................10

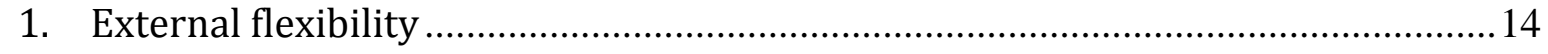

2. Internal flexibility: different practices within firms..........................................20

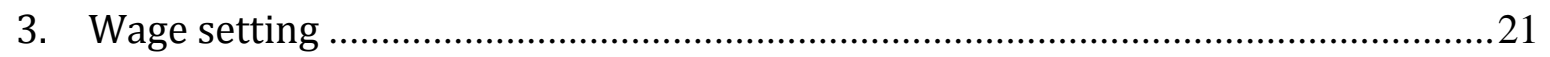

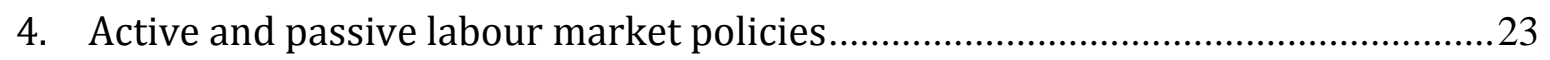

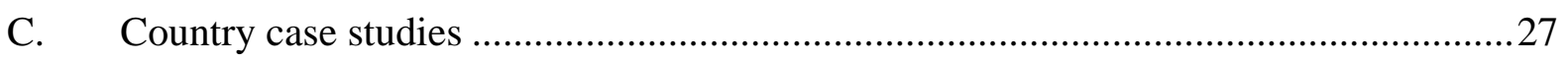

1. Germany: Employment stability despite strong export orientation ......................27

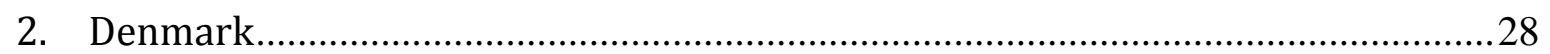

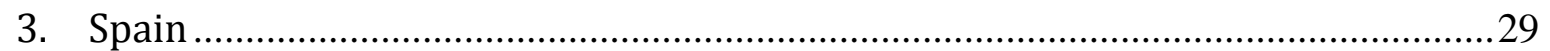

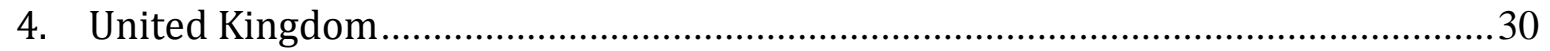

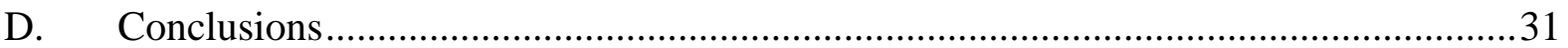

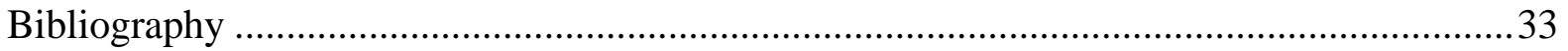




\section{Introduction and framework for the analysis}

Although the financial and economic downturn that began in 2008 was global in nature, the impact of the crisis - e.g. the intensity and timing - is rather heterogeneous across countries. However, there is much to learn about the nature of these differences in terms of impacts and what has worked in those countries to limit the labour market consequences of the economic shock.

Various factors influence the labour market effects of the crisis. The structure of the economy, for example, plays an important role as vulnerable sectors constitute a larger share in some countries than in others. In other instances, countries where the financial sector has a relatively high employment share - such as the United States and the United Kingdom and to a lesser degree Ireland - were hit first and hard as the crisis spread throughout the financial system. Similarly, countries are also affected by the varying degrees of exposure to downturns in housing markets, construction sectors and manufacturing exports.

In addition, fiscal efforts to address the consequences of the downturn were put in place by many governments soon after the effects of the crisis started to take shape. Globally, the IMF reported that the average size of discretionary fiscal measures in 2009 was 1.9 per cent of GDP in advanced G20 countries (approximately 30 per cent on infrastructure) and 2.2 per cent of GDP in emerging and developing G20 countries (approximately 50 per cent on infrastructure). ${ }^{1}$ Such measures had an undeniably positive impact as global growth for 2010 is expected to rise above 4.5 per cent. $^{2}$

Finally, another very important consideration, and the main focus of this paper, is the characterization of labour market institutions in place. Although less examined in the current context, labour market institutions - including in particular employment protection legislation, unemployment benefits and active labour market programmes (ALMPs) - have played a key role in absorbing and accommodating the severe shock and in mitigating immediate negative labour market and social impacts. In light of data constraints, the scope of the paper will be limited to the analysis of G20 and some EU countries where a range of economic, labour and institutional data is currently available.

The role of labour market institutions in determining employment outcomes has been a widely debated topic in recent research. For instance, there is evidence based on comparative panel data that finds wage setting, employment protection, active labour market policies, unemployment benefit systems and taxation have an impact on employment and unemployment rates ${ }^{3}$ and on job tenure. ${ }^{4}$ There is a lack of consensus about the specific contribution of particular institutional provisions while others disagree about the relative role of institutional factors vis-à-vis macroeconomic shocks. ${ }^{5,6}$ Moreover, researchers also point

\footnotetext{
${ }^{1}$ See Horton et al. (2009).

${ }^{2}$ According to the world output projections of the IMF (2010).

${ }^{3}$ See for example, Layard et al. (2005); and Bassanini and Duval (2006).

${ }^{4}$ See for example Cazes et al. (forthcoming).

${ }^{5}$ See Baker et al. (2005); and Eichhorst et al. (2008).

${ }^{6}$ See for example, Blanchard and Wolfers (2000).
} 
to the fact that interactions between institutions and more complex institutional arrangements can be more relevant than single institutions. ${ }^{7}$

A more integrated and dynamic perspective, however, suggests that institutional patterns interact with the macroeconomic perspective and that labour market outcomes are strongly influenced by the channels of employment adjustment in a certain institutional setting. While most research addresses the issue of institutional effects on unemployment persistence after a macroeconomic shock, it is also plausible to assume that institutions influence short-term adjustments in the labour market at the early stages of an economic crisis. ${ }^{8}$ This paper will attempt to clarify this analysis.

The analysis presented in this paper is organised in four parts. The first part (Section A) of the paper will focus on assessing the main labour market and economic indicators with a view to illustrating the extent and country variation in the impacts of the crisis. Section B will analyse the role of labour market institutions in shaping the different crisis outcomes among countries. In particular, against the backdrop of the cross-country labour market impacts of the crisis, this section considers that this heterogeneity is not just "accidental", but that it is influenced considerably by established core labour market institutions - i.e. initial employment protection (strict/loose), the generosity of unemployment benefits and active labour market policies as well as the structure of collective bargaining (i.e. centralised vs. decentralised and high vs. low coverage). Various clusters of countries will be defined by combining countries with similar labour market institutions and crisis outcomes.

The third section, Section C, will supplement the above analysis with a more detailed study of typical country cases. This will provide a more conclusive picture of the variety of the institutional setup in different countries and how they have shaped outcomes to date. Finally, Section D will conclude and suggest some policy instruments that may help shape an appropriate policy mix between short- and medium-term oriented policies.

\section{A. Labour market impacts}

\section{Since the onset of the crisis, employment losses were immediate and profound...}

In 2007, the rapid employment growth that preceded the crisis began to slow, and by 2008 all regions of the world of work had experienced a deceleration of employment growth. In the G20 countries, year-on-year employment growth fell from around 1.9 per cent to -1.2 per cent between the beginning of 2008 and the second quarter of 2009 (Figure 1, panel A). And although negative growth rates have started to decline, until the beginning of 2010 growth rates had not yet turned positive. When comparing year-on-year employment growth between the first quarters of 2010-09, 2009-08 and 2008-07, 14 of the 19 G20 countries analysed had moved to negative growth rates by the first quarter of 2009, and by the first quarter of 2010 only Turkey had returned to pre-crisis growth rates (Figure 1, panel B).

\footnotetext{
${ }^{7}$ See Hall and Soskice (2001); and Estevez-Abe et al. (2001)

${ }^{8}$ See Blanchard and Wolfers (2000); and Layard et al. (2005)
} 
Figure 1. Year-on-year percentage change in employment in G20, 2008- 2010

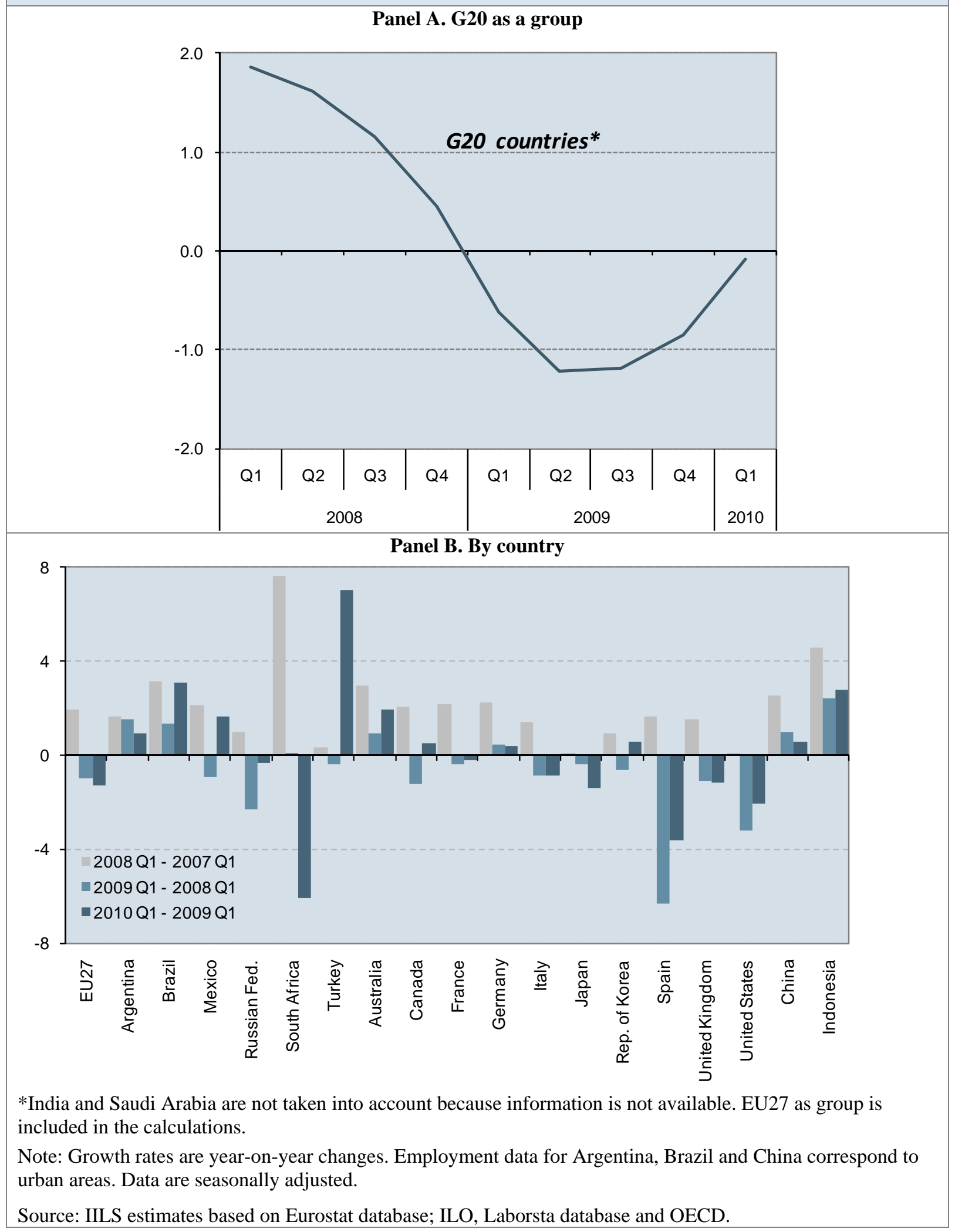

By early 2009, employment losses rose to historically high levels in a majority of countries (ILO, 2009). Some advanced G20 countries such as the United States and the United Kingdom were the first countries to experience employment contractions as the crisis spread 
throughout the financial system. ${ }^{9}$ In other advanced economies, job losses were initially contained but eventually accelerated as the effects of lower confidence and lower demand mutually reinforcing factors - took hold. For the EU 15, job losses totalled 6.2 million between the third quarter of 2008 and the first quarter of 2010.

Even among the emerging G20 countries, which were not affected directly by the financial crisis at first, job losses during the second and fourth quarters 2008 amounted to 2.5 million. ${ }^{10}$ Initially, the instability stemming from US sub-prime mortgages was contained and did not spill over to emerging and developing economies. But soon, the extent of the interlinkages emerged, and the negative effects of the financial turmoil spread to the real economy through a number of transmission channels. Particularly significant was the fact that trade volumes fell as a result of lower demand, and so export-oriented economies were deeply affected. Some countries were hit hard by the economic downturn and lower commodity prices, given the relative significance of manufactured exports and/or primary exports (e.g. Argentina); or by falling commodity prices for metals such as nickel, lead and zinc (e.g. Brazil and South Africa).

\section{And unemployment has risen to levels not seen during the past two decades...}

The combination of new labour market entrants and recent job losers looking for employment led in many cases to a rapid increase in the unemployment rate: in G20 countries the unemployment rate surpassed 9 per cent at the beginning of 2010 (Figure 2, panel A). Rapid increases have occurred across countries, with unemployment levels rising by close to 19 million between the first quarters of 2008 and 2010, bringing the total number of individuals unemployed in these countries to close to 74 million.

Between the first quarters of 2008 and 2010, the unemployment rate rose nearly 2.5 percentage points (Figure 2, panel A). And by country, among all G20 and EU countries analysed, only Argentina, Brazil, Germany and Indonesia experienced decreases in the unemployment rate (Figure 2, panel B). Over the same period, for the EU27, the rise in unemployment rates has been above the G20 average - 2.9 percentage points. The hardest hit Member State economies in the EU, in terms of the increase in unemployment, are Estonia, Latvia, and Lithuania, with changes above 13 percentage points. Spain follows a similar trend with its unemployment rate more than doubling increasing from 9.6 per cent in 2008 to over 20 per cent in 2010. Unemployment rates have also grown in the emerging G20 countries although less significantly (on average 1.8 percentage points in the seven quarters leading up to the first quarter 2010).

\footnotetext{
${ }^{9}$ See V. Escudero, 2009 "Effects of the Crisis on the Financial Sector: Trends and Policy Issues". See also Annex A for a discussion of the sectoral distribution of employment over the past two decades.

${ }^{10}$ This figure corresponds to a net calculation and as such it does not take into account the heterogeneity of the timing of the crisis effects. When the total amount of jobs lost per country is taken into account in the calculation (change from peak to trough, which is country specific), the total number of jobs lost increases to 8.3 million. Data are seasonally adjusted.
} 


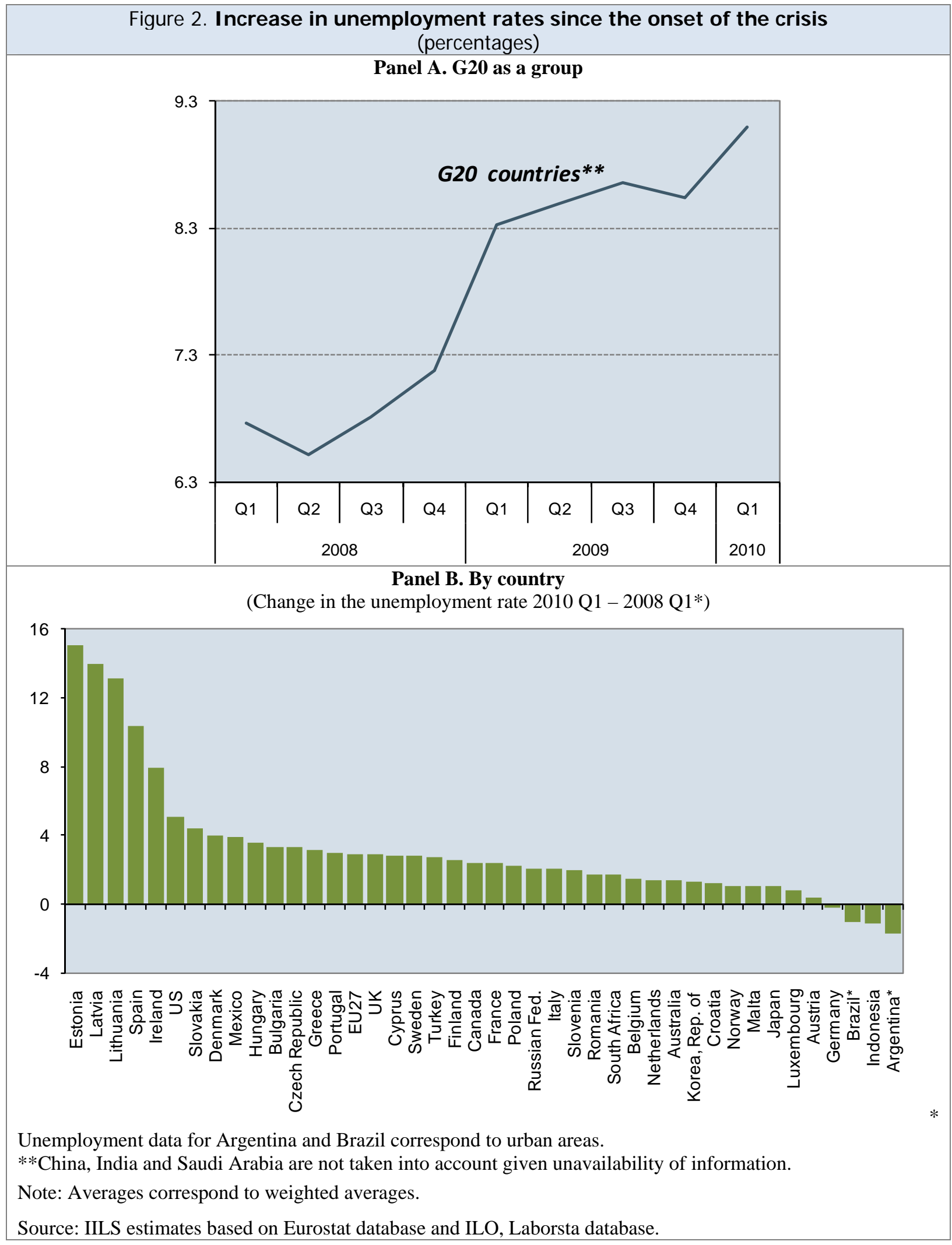


... which has increased the odds of structural unemployment.

Generally, inflow and outflow rates, to and from unemployment, tend to be cyclical, i.e. following upward and downward economic trends. ${ }^{11}$ More precisely, during economic recessions the inflow rate increases as people become unemployed and the outflow rate decreases as the slowdown in the economy makes it harder for unemployed workers to find jobs. Available data for a small group of advanced G20 economies regarding inflow/outflow rates provide key information about the dynamics of the labour market, especially with regard to potential weaknesses and strengths near turning points. ${ }^{12}$

Although this cyclicality holds true for all countries and periods analysed, the relationship between unemployment inflows and outflows differs across countries and has varied over time. ${ }^{13}$ During previous recessions increases in the inflow rate and decreases in the outflow rate were less severe; but during this recent crisis many countries have attained historical highs and lows. In the current context, there have been slow but continuous decreases in the outflow rate, which hints that the recovery too will be slower than previous downturns. Indeed, the current crisis appears to be marked by a shift in inflow and outflow rates from their performance during non-crises times but also from that of previous crises. The pace at which workers move into, and out of, unemployment has changed - with potentially pervasive effects for workers and employers (Figure 3).

\footnotetext{
${ }^{11}$ For analysis of the US labour market, see Daly et al. (2009); Tasci and Fee (2009). For analysis of other European and OECD countries see Elsby et al. (2008); Albaek and Sørensen (1998); Petrongolo and Pissarides (2008); Bertola and Rogerson (1997); Pissarides (1986).

${ }^{12}$ This analysis is based on updated figures (for 2007, 2008 and estimates for 2009) of the workbook produced by Elsby et al. (2008).

${ }^{13}$ Lack of available information regarding quarterly unemployment rates and annual unemployment levels by duration made it impossible to extend this analysis to countries beyond the OECD.
} 


\section{Figure 3. Evolution of inflow and outflow rates in the G7 countries, 1989-2009}

Panel A. Canada, Japan, United Kingdom and the United States

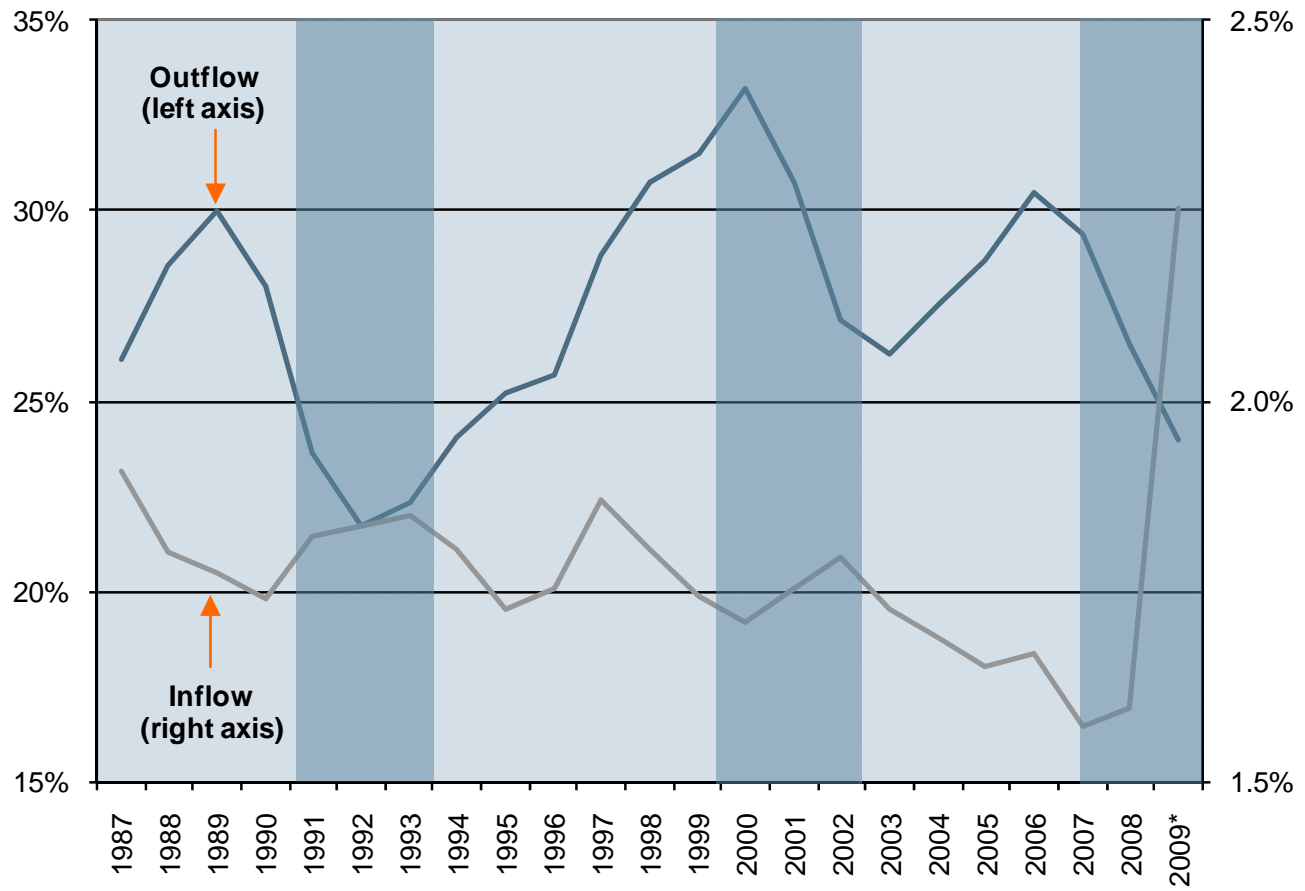

Panel B. France, Germany and Italy

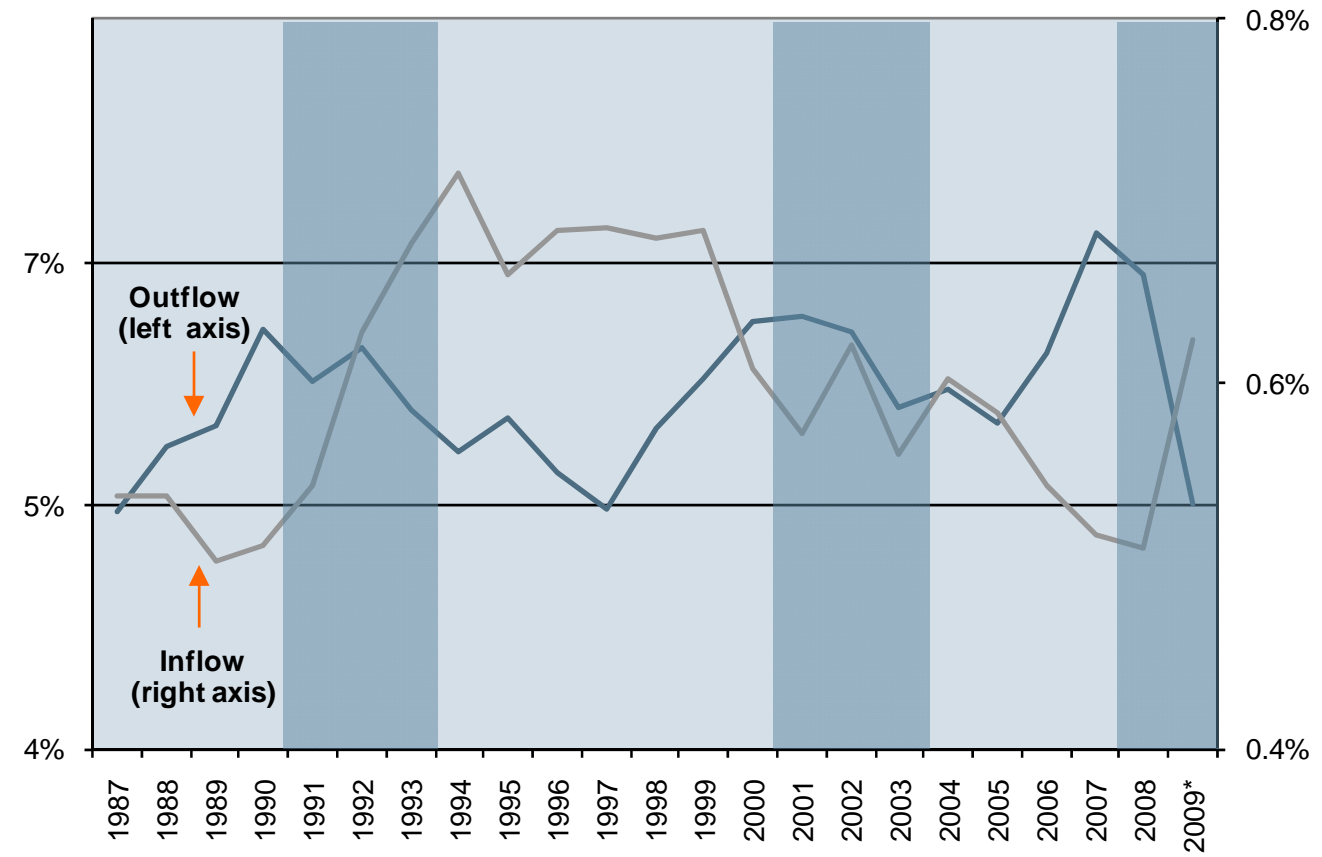

Notes: Figures for 2009 are estimations. The onsets of crisis periods are defined as the first point of sustained moderation of economic growth. Shaded areas therefore show GDP recession years from that point onwards.

Source: IILS estimates; Elsby et al. 2008 and OECD statistics.

In fact, in examining previous recessions, the unemployment rate continues to rise even as job losses slow and the inflow rate starts to decline (this lag pattern reflects the fact that firms 
generally do not resume hiring until the recovery is well under way). ${ }^{14}$ During the 2001 recession, for example, outflow rates remained low because firms were slow to hire. The current high share of workers on reduced working hours or who are now employed part-time, either voluntarily or involuntarily, suggests that employers are likely to tap into existing workforces (part-time employment and temporary workers) rather than hiring new workers. ${ }^{15}$ This would result in a very slow pick-up of the outflow rate, adding to the risks of jobless recovery and a structural increase in unemployment in the medium-term.

The impact of the crisis varies significantly from country to country.

Significant cross-country differences exist in terms of the labour market impacts of the current economic crisis (Figure 4). Analysing the evolution of economic and employment growth since the onset of the crisis suggests several trends:

- Among the advanced G20 countries analysed, the best-off countries (relative to the developed countries' median) ${ }^{16}$ are Australia, Belgium, Canada, France and the Republic of Korea. The countries hardest hit to date seem to be Finland, Japan and Luxembourg in terms of output losses and Spain in terms of employment losses, with Ireland the most affected country on both fronts. ${ }^{17}$

- Among the emerging G20 countries analysed, Indonesia, Malta and Cyprus, for example, were the least affected on both fronts (relative to the median of the group). Argentina and Brazil are also good examples, especially in terms of the employment effects. Latvia, Estonia and Lithuania, were the hardest hit both in economic growth and employment losses; and Turkey and the Russian Federation suffered from big economic losses relative to other countries, but less employment losses.

- In the majority of G20 countries, employment losses were less severe compared to GDP declines. Exceptions include Ireland, Poland, Portugal, Slovakia, South Africa, Spain and the United States.

- To the first quarter of 2010, employment in 30 per cent of the advanced G20 countries and 40 per cent of the emerging G20 countries continued to be affected by the crisis. What is more, two years after the onset of the crisis, only 1 advanced country and 8 emerging ones has fully recovered pre-crisis employment levels. ${ }^{18}$

\footnotetext{
${ }^{14}$ See, for example, Daly et al. (2009).

${ }^{15}$ For a more in depth analysis of policies to retain employment during the current crisis, please see section A of the World of Work Report 2009 (ILO, 2009a).

${ }^{16}$ GDP growth and employment were analysed relative to the median of growth and employment changes for the group of countries analysed.

${ }^{17}$ Throughout the course of 2010, countries like Greece, Ireland, Portugal and Spain are also confronted with a number of fiscal challenges.

${ }^{18}$ For more detail on the employment recovery analysis, see Chapter 1 of the World of Work Report 2010 (ILO, 2010a).
} 


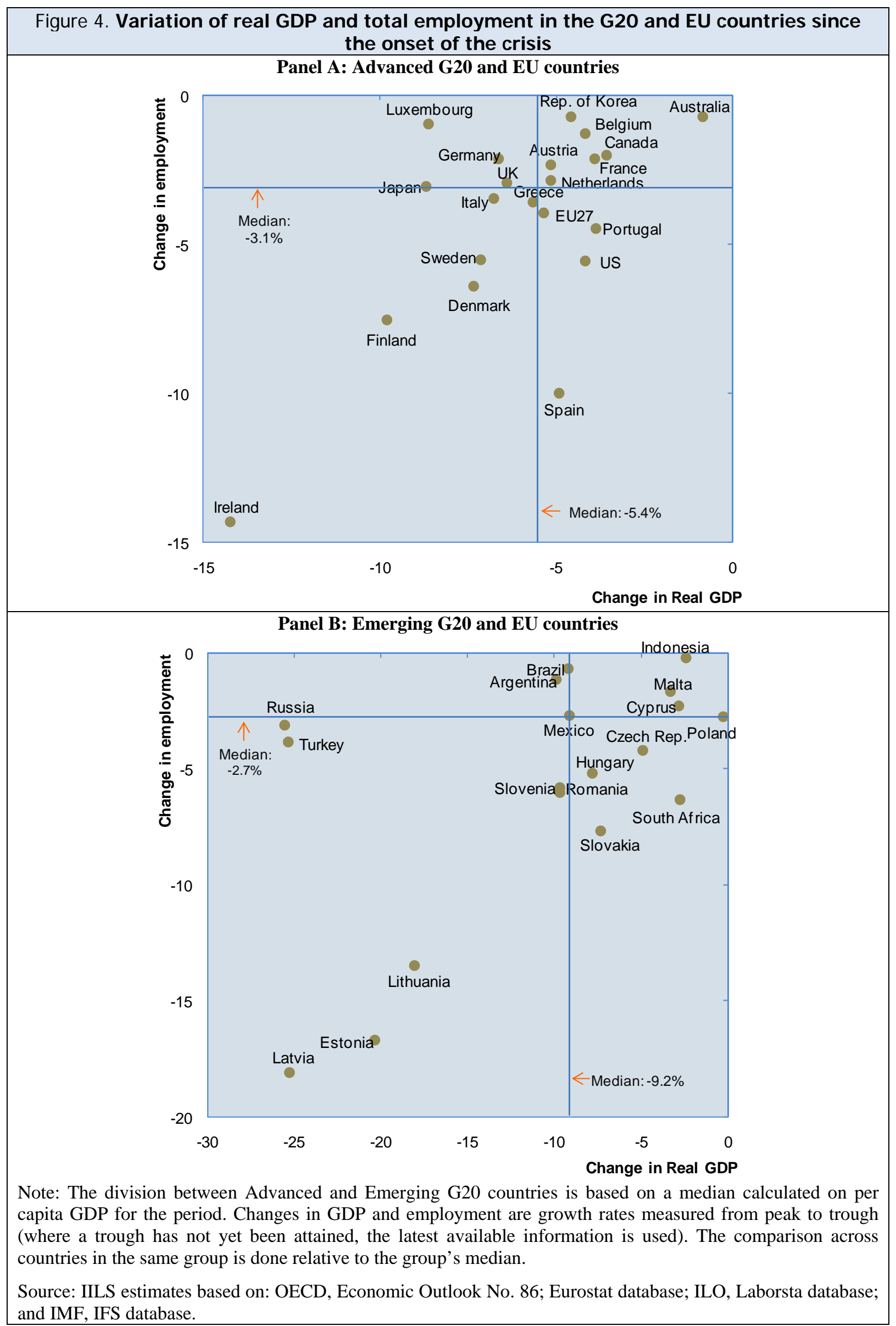




\section{B. Factors influencing the labour market impacts of the crisis}

As seen in the previous section, countries have responded to varying degrees to the crisis, and with varying degrees of success. A number of factors have moderated the labour market impacts of the crisis on individual countries. For starters, fiscal stimulus packages especially those that were timely and properly targeted - played a key role in alleviating the negative effects of the crisis (Figure 5). In some cases, e.g. Thailand, Kazakhstan and China, the measures as a percentage of GDP far exceed 10 per cent. Of course, fiscal stimulus was very much a function of initial conditions and adequate fiscal space.

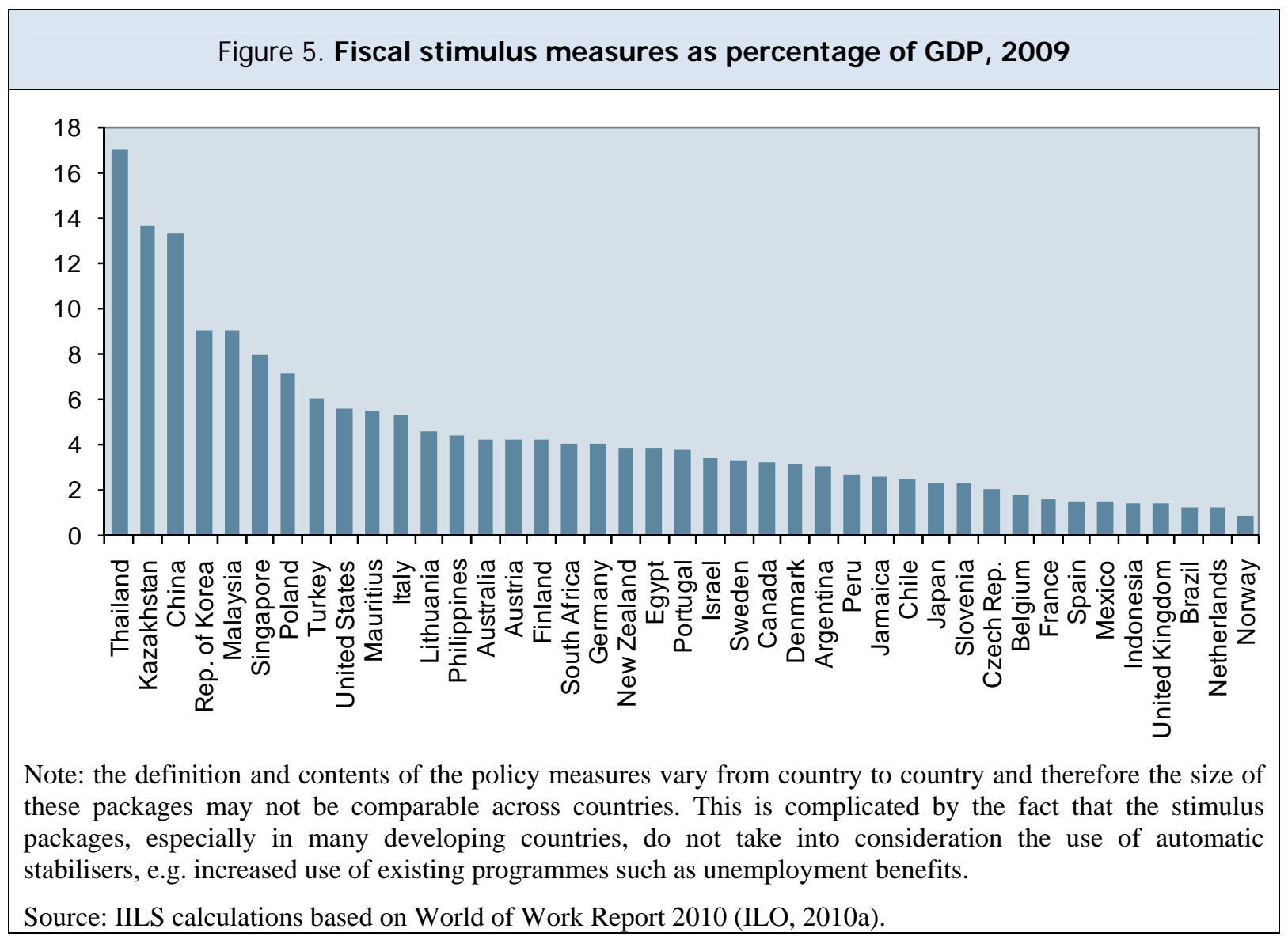

The structure of the economy also plays an important role, as vulnerable sectors constitute a larger share in some countries compared to others, i.e. sectors that tend to be affected by the global economic crisis significantly. In particular, countries which rely heavily on manufacturing (such as many CEE countries) suffered from a severe output shock in this segment (Figure 6). In other cases, given that the crisis started to some extent in the housing sector, countries like Spain with relatively large construction sectors were dramatically hit by employment losses in these sectors. 


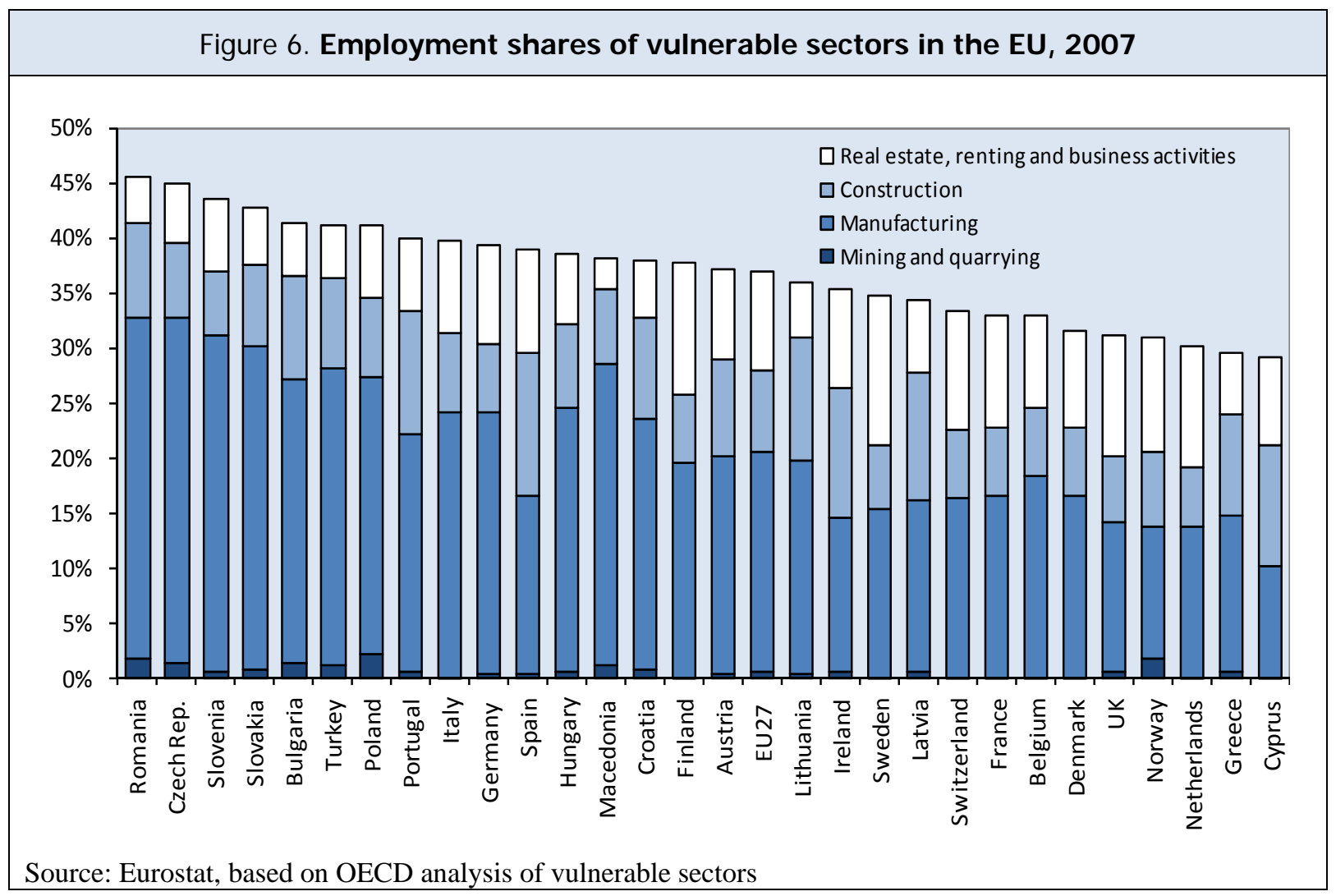

Another important consideration in this regard - although less studied - is the capacity of labour market institutions (EPL, wage setting, unemployment benefits and ALMPs) to absorb and accommodate shocks. In order to develop a more integrated and dynamic perspective on adjustment to external shocks, external flexibility defined by typical labour market institutions cannot be seen as the only channel of influence. Following the classical work of Atkinson (1984), the dimension of internal flexibility warrants attention, and it is worth distinguishing between functional and numerical flexibility. Indeed, four different types of labour market flexibility can be distinguished:

- External numerical flexibility: the possibility to adapt the number of employees to the economic situation. Determinants are the strictness of employment protection for open-ended and fixed-term contracts and the quantitative availability of labour.

- Internal numerical flexibility: achieved without variations in the number of staff. Allows for adjustment of working time via overtime or working time accounts in order to meet a company's current utilisation rate.

- External functional flexibility: requires a skilled labour force adaptable to structural changes. A prerequisite for an adaptable labour force is the provision of appropriate primary, secondary and tertiary education to create a basis for life-long learning. Skill mismatch in the labour market can be avoided by promoting occupational mobility through active labour market policies, in particular job placement and training.

- Internal functional flexibility: ability to react to changing demand with a flexible (re)organisation of the production process. This requires broad and well-educated employees able to perform different tasks.

Furthermore, adjustment of wages is an additional element of flexibility. 
Regarding labour market institutions, it is useful to differentiate between employment protection on the one hand and labour market policies - active and passive - on the other. ${ }^{19}$ This helps to identify various possible models of flexibility, e.g. countries with strong dismissal protection have alternative options to compensate for a lack of external flexibility such as working-time flexibility. Table 1 summarises the various flexibility models.

Table 1. Flexibility models

\begin{tabular}{|c|c|c|c|}
\hline & & \multicolumn{2}{|c|}{ Employment protection (core) } \\
\hline & & Strong & Weak \\
\hline \multirow{2}{*}{ 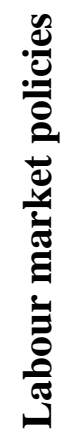 } & Big & $\begin{array}{c}1 \\
\text { (Continental countries, } \\
\text { e.g. Germany) }\end{array}$ & $\begin{array}{c}3 \\
\text { ("Flexicurity" countries, } \\
\text { e.g. Denmark) }\end{array}$ \\
\hline & Small & $\begin{array}{c}2 \\
\text { (Mediterranean/ } \\
\text { Roman/Latin countries, } \\
\text { e.g. Spain) }\end{array}$ & $\begin{array}{c}4 \\
\text { (Anglo-Saxon countries, } \\
\text { e.g. United Kingdom) }\end{array}$ \\
\hline
\end{tabular}

Source: IZA.

With this in mind, this section takes a closer look at three kinds of labour institutions: (i) those related to external flexibility (e.g. dismissal protection, fixed-term employment, temporary agency work); (ii) those related to internal flexibility (working time reductions, wage flexibility and subsidised short-time work schemes); and, (iii) policy/programme buffers such as active labour market policies (employer subsidies, placement, training) and unemployment benefits (contributory as well as means-tested).

For the purpose of this analysis, various clusters with similar patterns of flexibility were created, based on an indicator developed by Eichhorst, Marx and Tobsch (2009). Due to data limitations on internal flexibility, however, the analysis has been divided in two groups: one with external and wage flexibility only, and one including internal flexibility. Starting with the former, the groupings strongly resemble established typologies (Figure 7). The first cluster comprises nine Scandinavian and Continental-European countries and can be labelled 'education-based'. It is characterised by low external numerical and wage flexibility alongside high external functional flexibility. The second cluster (Asian and the Anglo-Saxon countries) combines high external numerical and wage flexibility with intermediate external functional flexibility and can be called 'market-oriented I'. The third group consists of the four CEE countries, which have high external functional and wage flexibility, but very low external functional flexibility ('market-oriented II'). Finally, the Southern European cases form a cluster which is characterised by rather low flexibility in all dimensions ('low flexibility cluster').

\footnotetext{
${ }^{19}$ It is important to note that in many emerging and developing countries, labour market adjustments tend to be associated with increases in informal employment - a factor which is not captured by the more formal institutional setting.
} 
Figure 7. Cluster Tree external and wage flexibility, 2003

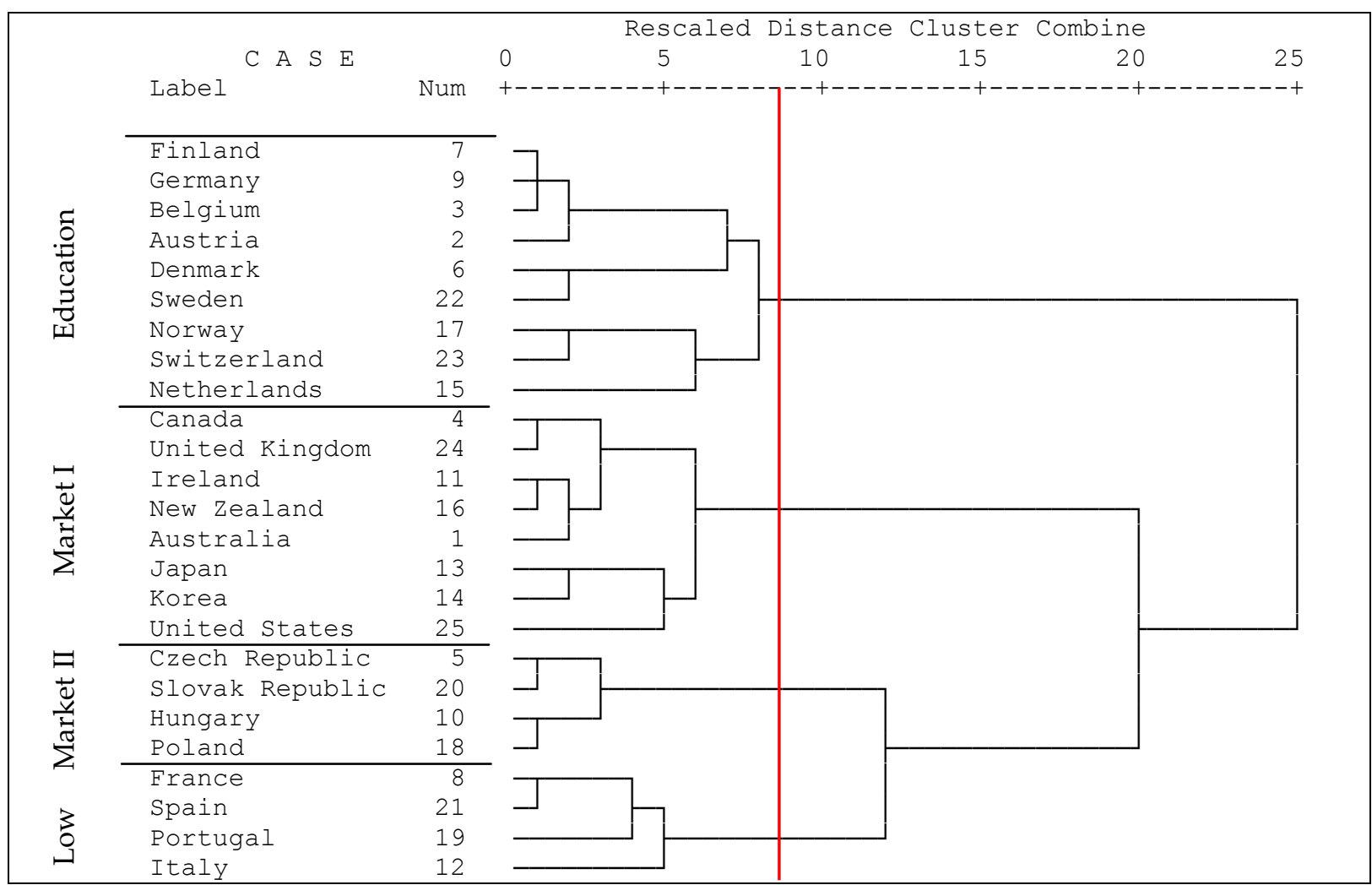

Source: IZA estimates.

Results of the second cluster analysis including internal flexibility are reported in Figure 8. With respect to external flexibility, the Continental and Scandinavian countries are quite similar, although Denmark and Sweden are treated as a separate cluster as both exhibit strong internal numerical flexibility, while internal functional flexibility prevails. As such, functional elements (internally and externally) are very important in Denmark and Sweden so that their cluster is termed 'functional model'. The remaining Scandinavian countries together with the Continental countries form the second cluster, are characterised by an extensive use of working-time arrangements (especially Germany, Finland and France), but only by intermediate functional flexibility. In the third cluster, internal flexibility is clearly underdeveloped. It is formed by three Southern European countries ('low flexibility model'). And finally, the fourth cluster consists of cases that reveal very high external and wage flexibility and is therefore labelled 'market model'. The heterogeneous group comprises two Anglo-Saxon and three CEE countries. Contrary to what one might expect, most of these countries do not completely lack internal flexibility, but display an average level of both subindicators. The following sections analyse each dimension of labour market flexibility in more detail. 
Figure 8: Cluster Tree overall flexibility, 2003

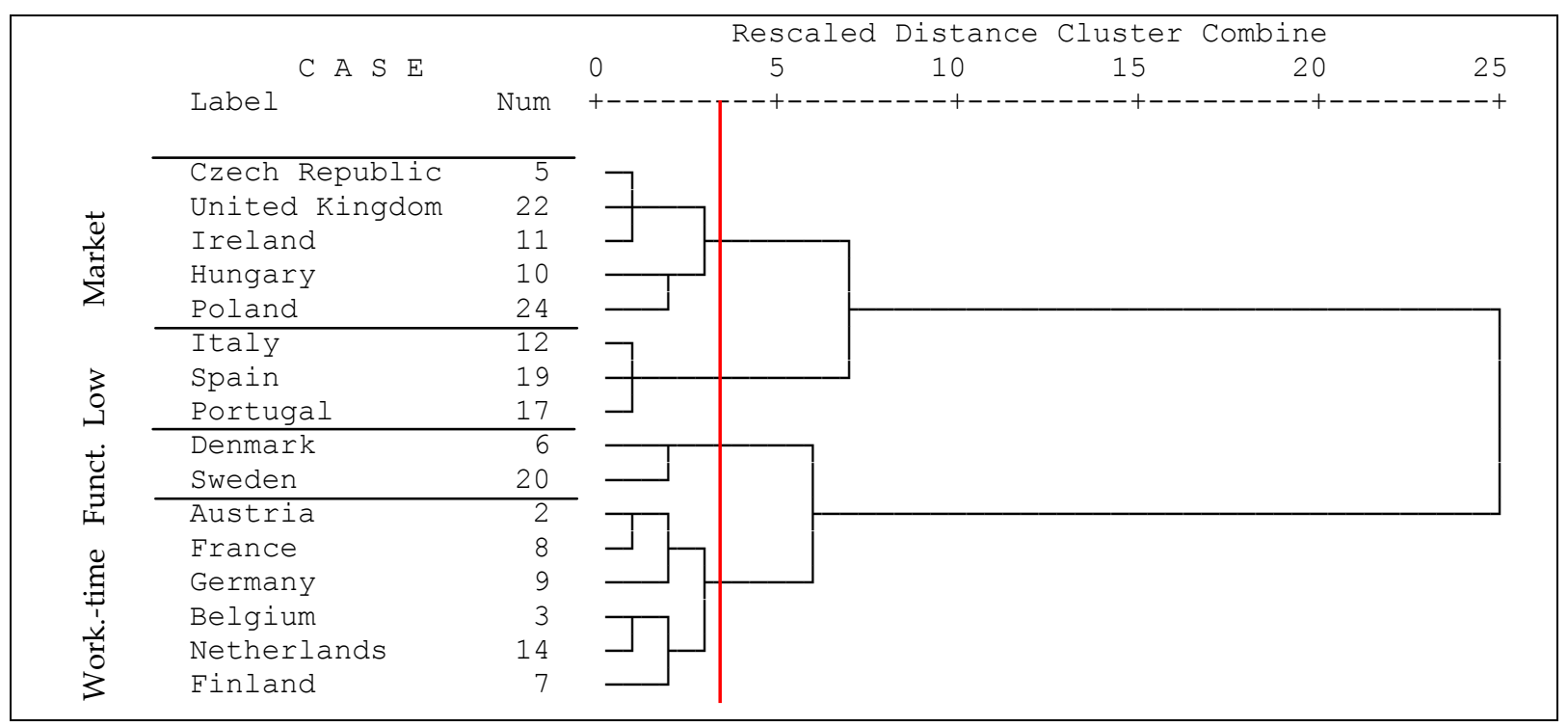

Source: IZA estimates.

\section{External flexibility}

In times of crisis, the debate regarding the appropriate level of strictness of employment protection gains momentum. A certain level of regulation is necessary in order to protect workers from arbitrary decisions regarding dismissals and the use of temporary contracts, as well as to have firms internalize some of the social costs of labour turnover. However, excessive employment protection may also restrain the ability of firms to quickly respond to technological changes and consumer demand, as well as the capacity of a national labour market to adapt to sudden economic shocks. Finding a balance between protecting workers and allocating labour to its most productive use is therefore a key priority for policy makers, drawing on a range of policy measures including employment protection.

This section examines: a) the different levels of EPL strictness across the G17 countries for which information is available and b) the variation of such strictness during the last two decades in order to shed light on how these changes may have affected the impact of economic downturns on employment. ${ }^{20}$

\footnotetext{
${ }^{20}$ Data for this analysis is taken from the employment protection database of OECD, which provides information for 17 of the 19 G20 countries (information for Argentina and Saudi Arabia is not yet available). A number of EU countries with available information have also been included. These countries are: Austria, Belgium, Czech Republic, Denmark, Estonia, Finland, Greece, Hungary, Ireland, Luxembourg, Netherlands, Poland, Portugal, Slovak Republic, Slovenia and Spain.
} 


\section{EPL varies considerably across countries...}

The level of stringency of employment protection varies significantly across countries and across type of EPL (Figure 9). Overall, among the G17 countries, the strictest employment protection of temporary forms of employment is in Turkey, Mexico and Brazil, while the least strict is in Canada, the United States and the United Kingdom. Regarding protection of permanent workers, Indonesia, Portugal, India and China are at the top, whilst the United States and to a lesser degree Canada and the UK are at the bottom in terms of strictness of regulation. It is noteworthy that much of the cross-country variation in overall employment protection is due to differences in the level of regulation on temporary contracts. ${ }^{21}$ Finally, countries with the highest amount of specific requirements for collective dismissal are Italy, Belgium and Luxembourg, whereas in Brazil, India and Indonesia these requirements have not yet been included in their legislation for employment protection.

When comparing averages between high and medium GDP per capita countries other interesting findings arise: the overall indicator for both groups of countries is relatively close (2.2 and 2.48, respectively in a scale of 0 to 6). Regulations on regular contracts are slightly stricter in the medium GDP per capita group, mainly because of more stringent regulations in China, India and Indonesia. On the contrary, additional requirements for collective dismissal are less severe in the emerging group given that Brazil, India and Indonesia have no such arrangements. It is important to take into account, however, that strictness of employment protection may have less of a meaning in developing countries where informal employment is prevalent.

\footnotetext{
${ }^{21}$ There are generally few or no restrictions on the use of temporary contracts in the Anglo-Saxon countries. In contrast, in Turkey and Mexico, temporary agency work is illegal and fixed-term contracts can only be used in limited circumstances.
} 


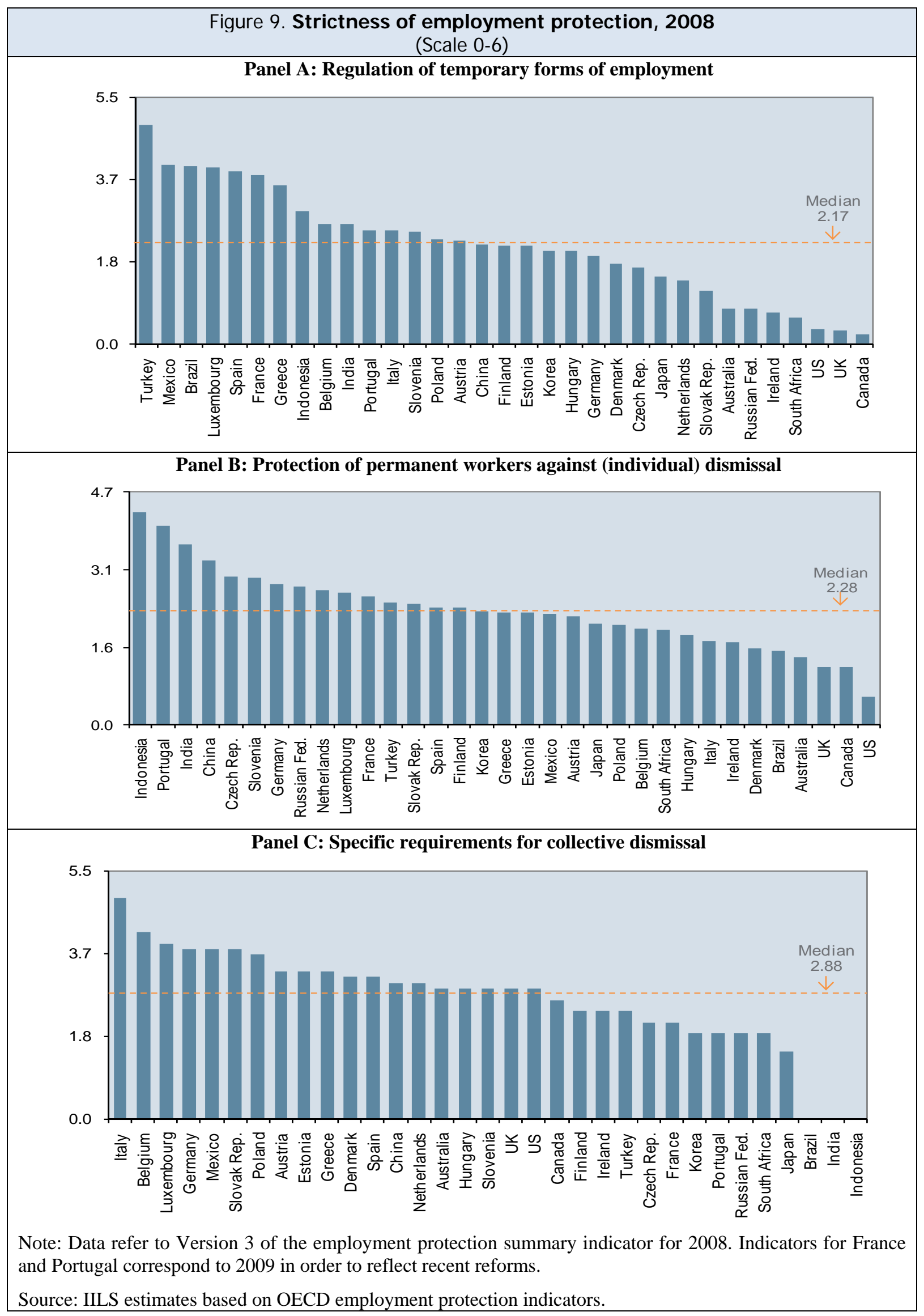


... and has changed in the current era of globalisation.

Since 1992 the dominant tendency among countries for which information exists has been a reduction in the strictness of employment protection. Moreover, countries with the highest levels of employment protection exhibit some of the largest reductions (e.g. Belgium, Italy and Spain). ${ }^{22}$ In general, most of the relaxation of the level of employment protection is associated with facilitating temporary work (Figure 10). But there are also countries (Denmark, Finland, Republic of Korea, Netherlands, Portugal and Spain) where wide-ranging changes have reduced stringency of regulation for both permanent and temporary contracts. Finally, in Belgium, Germany and Greece increases in the stringency of regulation in some areas were offset by relaxation of regulation in others. This is the case of Germany where an extension in the duration of fixed-term contracts was permitted - specifically for the hiring of older unemployed workers and for cases in which new businesses were created - but at the same time a legislated compensation for dismissals was established.

\footnotetext{
${ }^{22}$ The exceptions are France, where the trial period for regular contracts was increased; Mexico, which shows no change; and Turkey, which despite having one of the highest levels of stringency shows a minor reduction in the protection for regular workers' dismissals. See Venn (2009).
} 


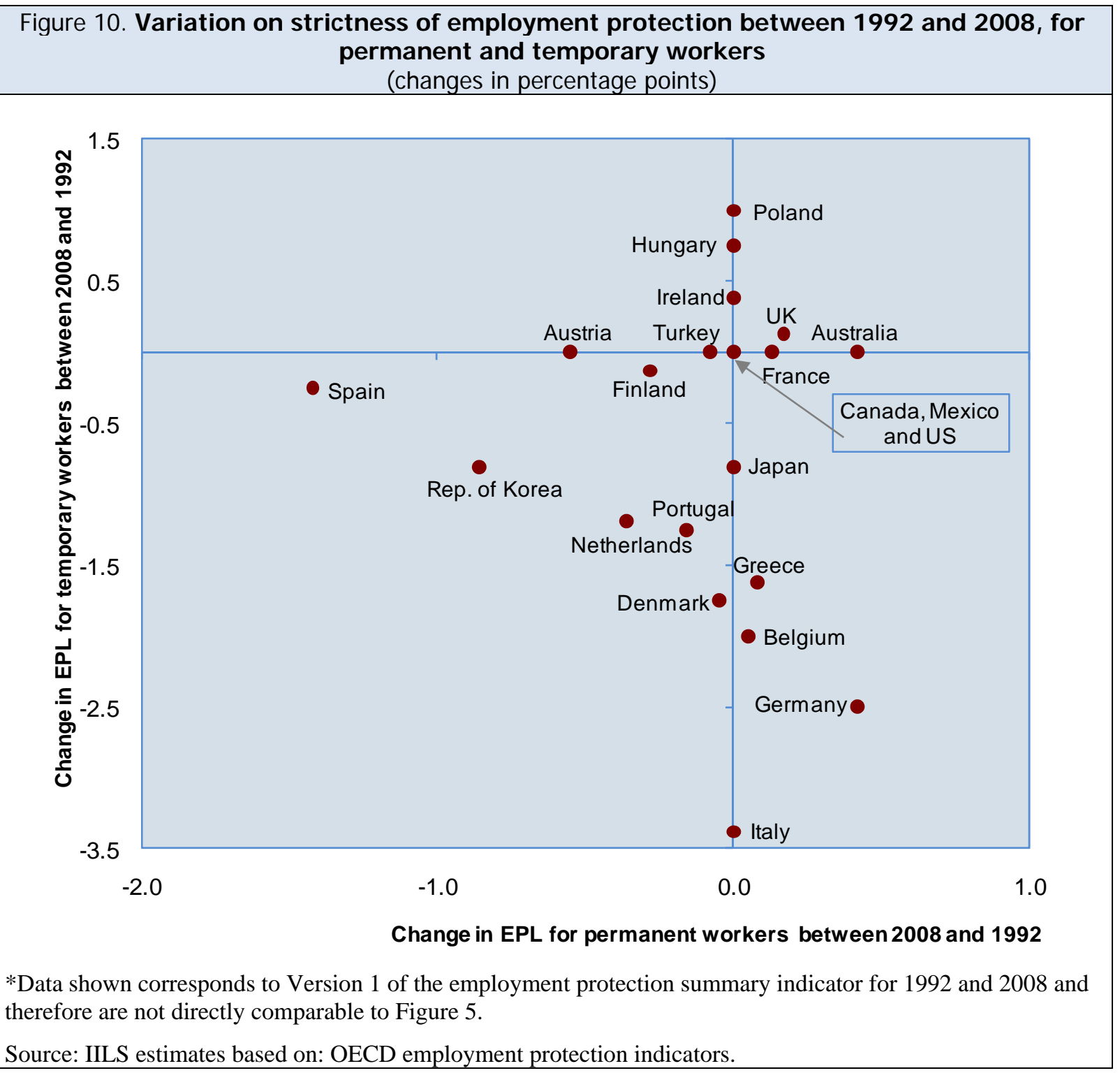

\section{And although of great importance, EPL does not seem to have had a direct effect in shaping the impact of the current crisis on employment.}

On the basis of the different flexibility models explained above (Table 1) one could expect that countries with strong employment protection for the core labour force will see a decline in 'atypical jobs' first - and probably only there - with total employment remaining more stable (at least initially). However, evidence is mixed for the group of countries analysed (Figure 11): ${ }^{23}$

- With little exception, temporary workers have borne the brunt of employment losses across countries.

- Some of the countries with high employment protection against dismissal for regular workers (e.g. Slovenia) indeed show higher employment losses of temporary workers

\footnotetext{
${ }^{23}$ This finding is consistent with the theoretical and econometric results that the costs and benefits associated to the existence of employment protection legislation are rather inconclusive. See for example, Freynes (forthcoming).
} 
than of their core employees. However, comparisons with other countries with lower employment protection for their core labour force often show lower employment losses.

- This phenomenon does not seem to be restricted to countries with high EPL for permanent workers. Countries with low (e.g. Ireland and Italy) and medium (e.g. Estonia, Finland, Hungary Luxembourg, Slovak Republic and Sweden) levels of EPL for regular workers exhibit similar relationships between the effect of the crisis on total and temporary employment.

\section{Figure 11. Variation of total and temporary employment since the onset of the crisis by strictness of employment protection for permanent workers against dismissal, select countries (in percentages)}

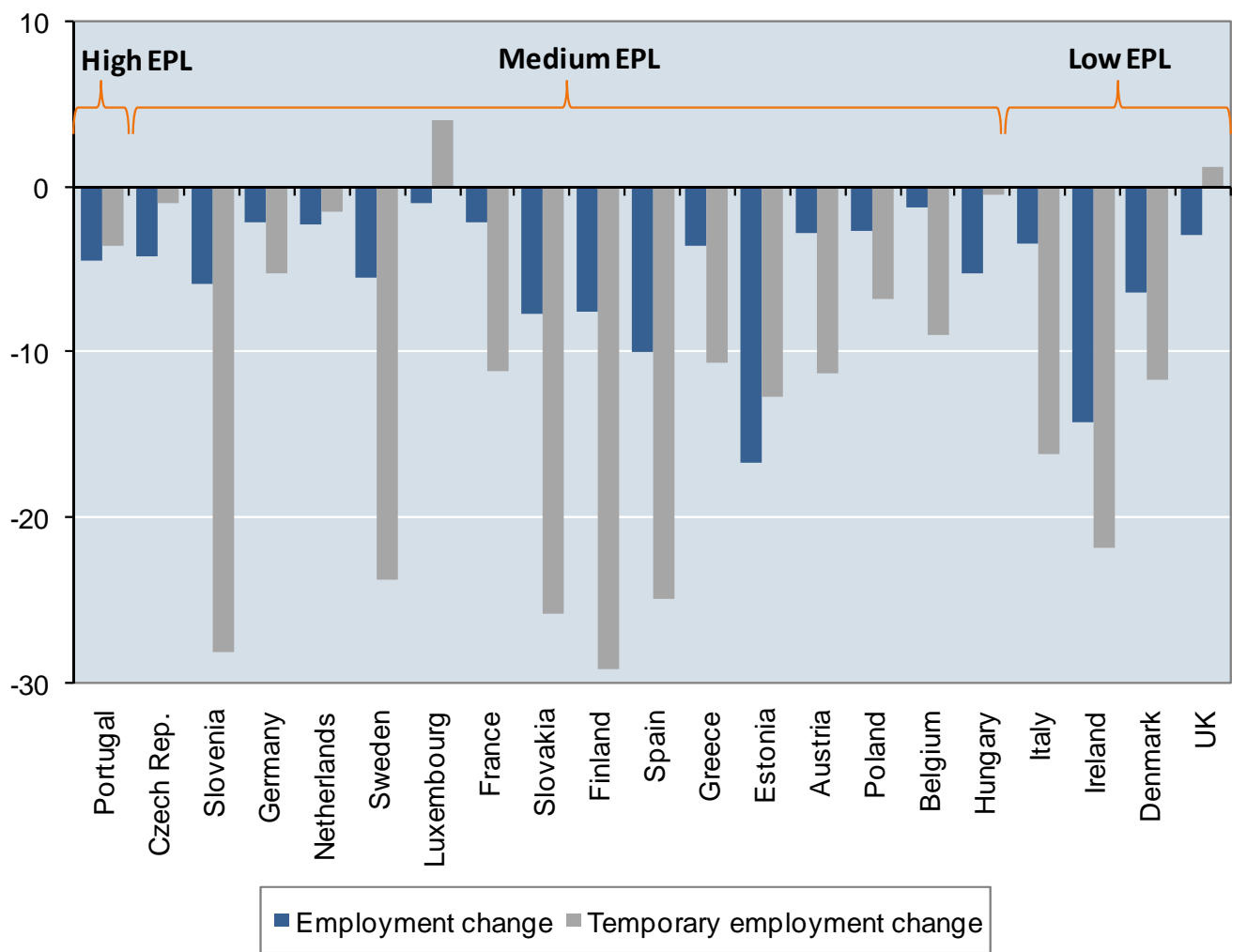

Note: Changes in temporary employment are changes measured from peak to trough (by quarter); where a trough has not yet been attained, the latest available information is used. The beginning of the crisis is countryspecific and is measured as the first term showing a negative change in total employment.

Source: IILS estimates based on: OECD employment protection indicators; Eurostat database; and national statistical offices.

Even when analysing the issue of employment protection legislation for regular workers and its role in shaping the outcomes of the crisis more generally - i.e. output and employment $-\mathrm{a}$ rather ambiguous relationship arises. Indeed, as Figure 12 indicates the impacts of the crisis in terms of GDP and employment appear to have little to do with the level stringency of employment protection. Some of the least affected G20 countries (e.g. Australia and to a lesser extent Argentina and Brazil) as well as the hardest hit (e.g. Ireland) have comparably low levels of EPL. 


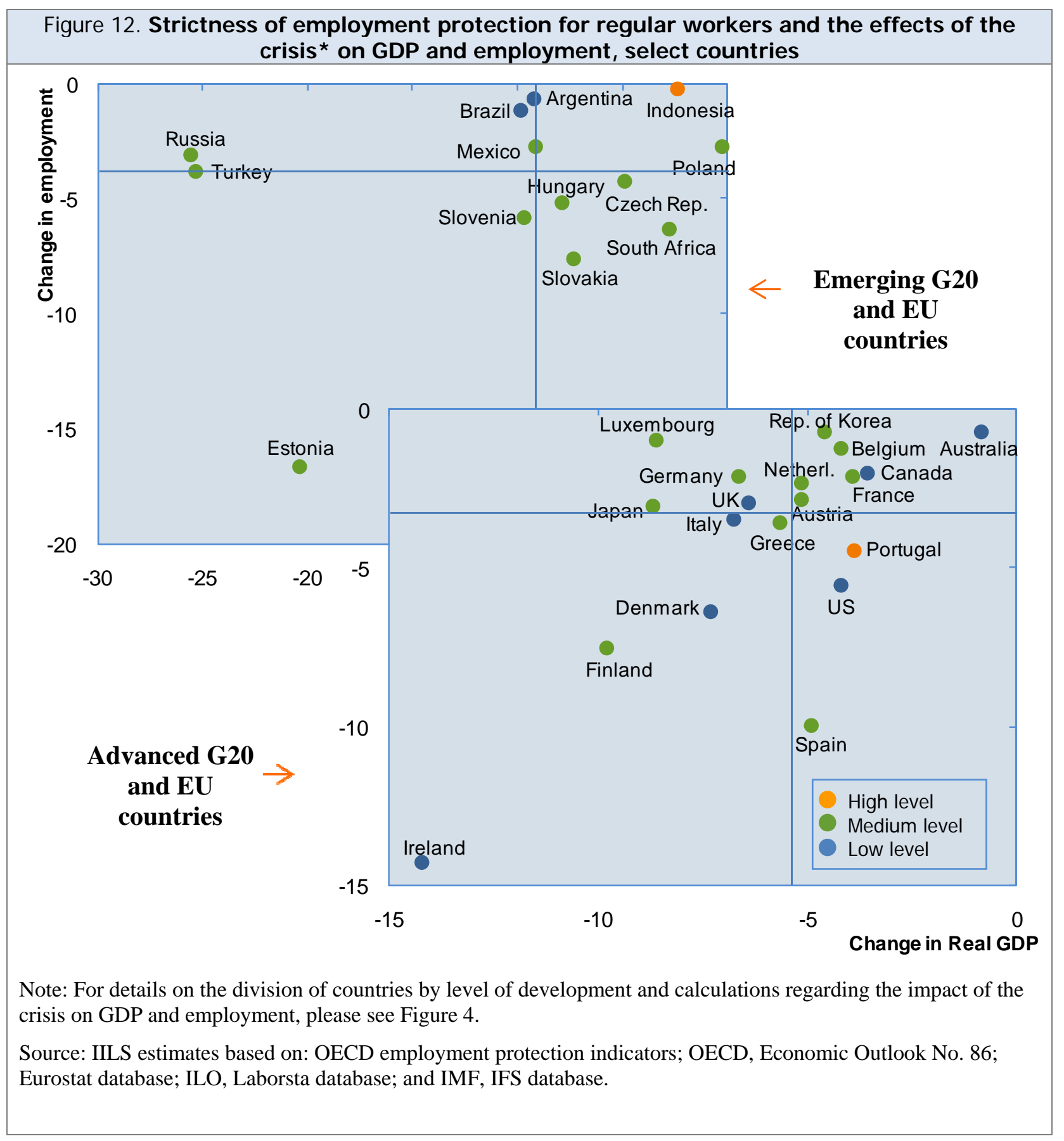

\section{Internal flexibility: different practices within firms}

Instruments of internal flexibility have been widespread during the crisis to limit employment losses. Among 33 countries (G20 and EU27), 31 have experienced significant falls in working hours since the onset of the crisis (-2.1 per cent on average, Figure 13). This is in stark contrast to the increases (22 of 33 countries) experienced in hours worked between 2007 and 2008 (ILO, 2009). Following these changes - not surprisingly - the incidence of parttime employment in total employment has also increased since the onset of the crisis in 25 of the 31 countries analysed. However, when analysing these changes in terms of the stringency of employment protection across countries, no clear relationship is evident. Indeed, countries from the three levels of EPL have experienced the largest reductions in the number of hours worked. 
Figure 13. Change in average number of hours worked per employed person, by level of EPL (in percentages, Q2 2009 - Q2 2007)

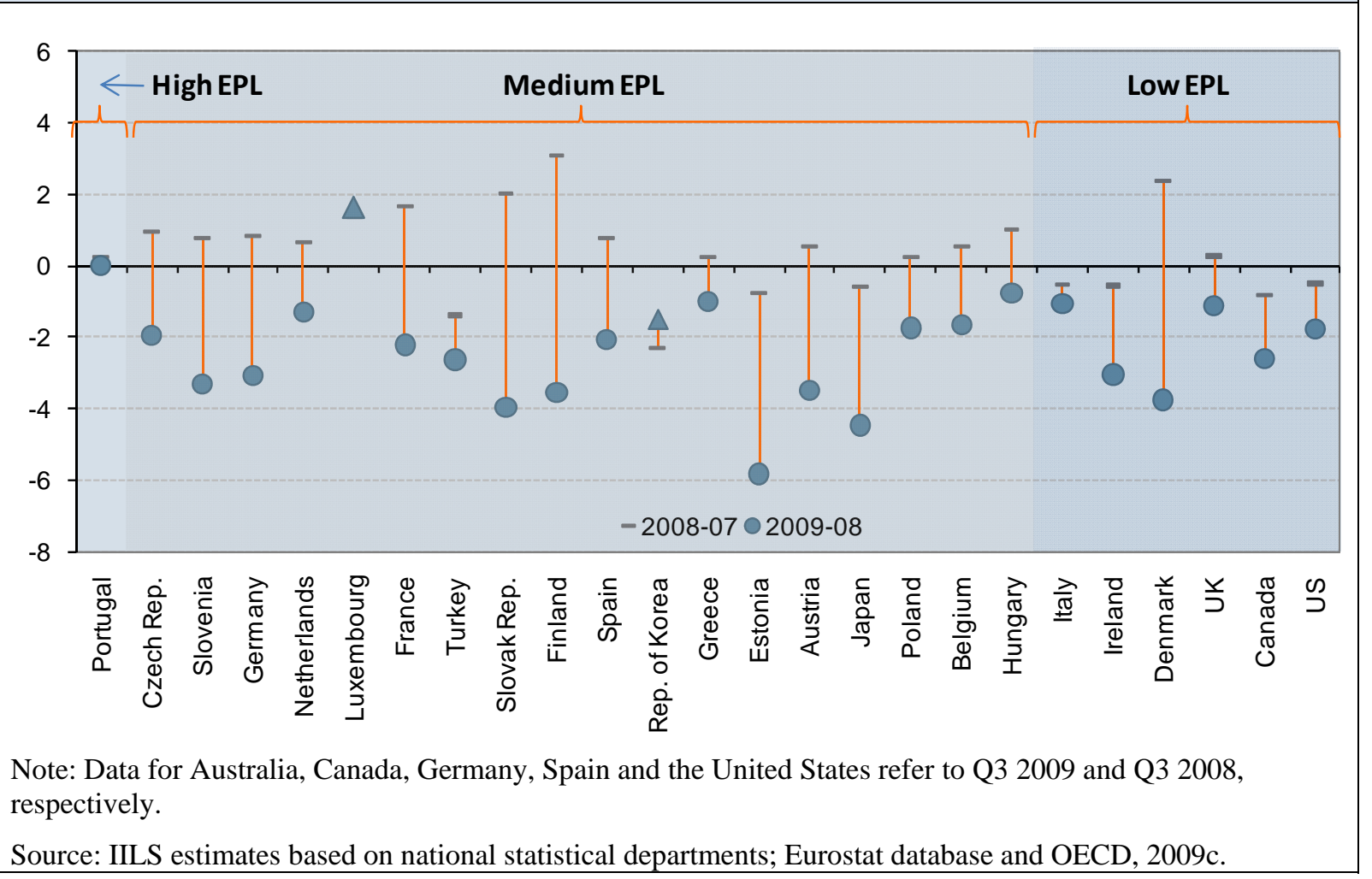

\section{Wage setting}

Wages - in particular wage cuts - can also act as an adjustment mechanism in times of crisis. In fact, countries which have managed to limit employment losses in comparison to other countries (e.g. Japan, Germany, Indonesia and the Republic of Korea) are also countries where real wages have fallen (or grown less) than in other countries (Figure 14). In some cases, e.g. Japan, this is associated with falling hours worked per week due to employment sharing schemes. In other countries, e.g. the Republic of Korea, it is the result of negotiations between social partners to save jobs. 


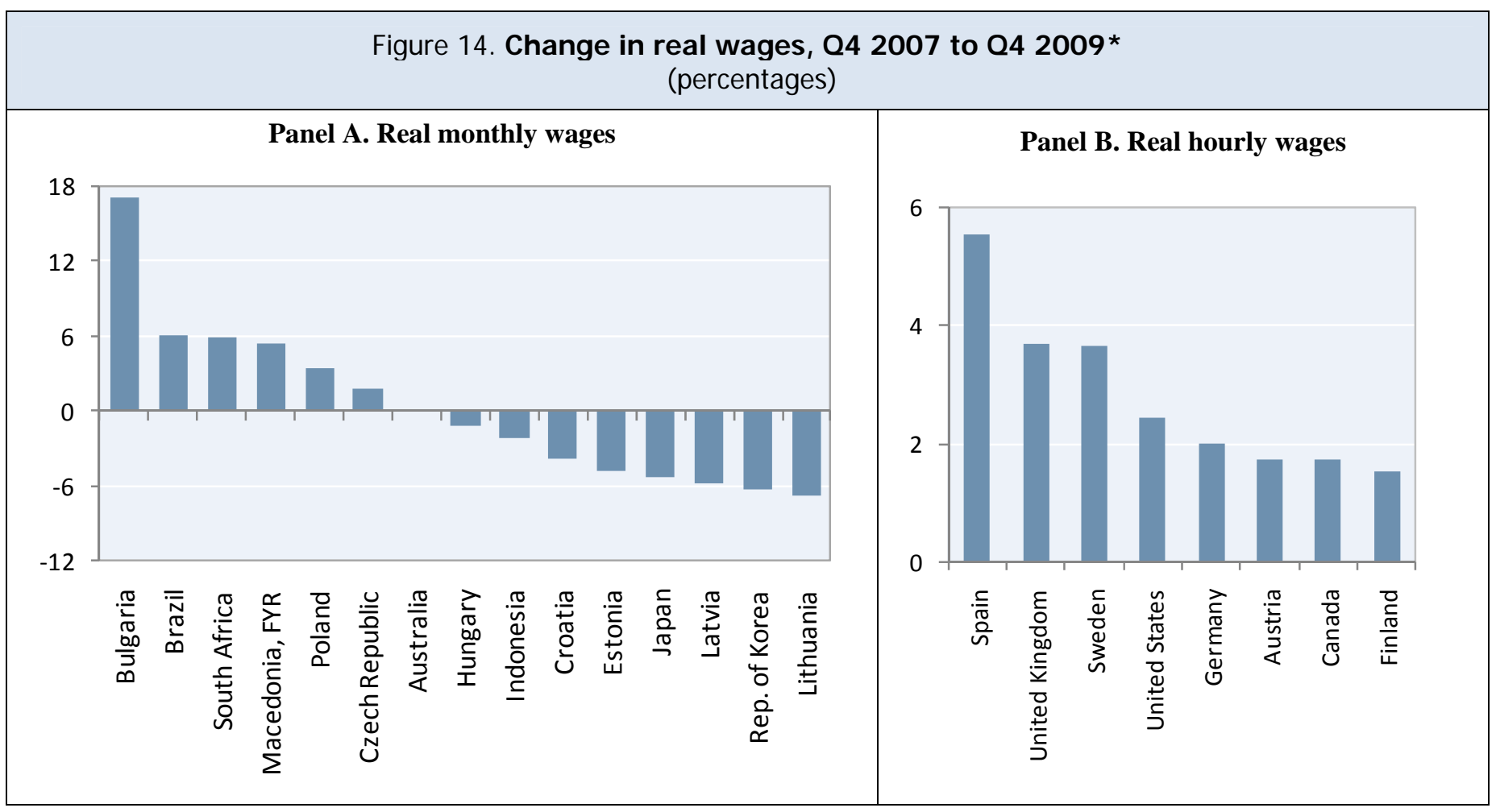

Note: *Changes for the Republic of Korea correspond to the period Q1 2007-Q1 2009; for Finland to the period Q2 2007-Q2 2009; and for Austria and the United Kingdom to the period Q3 2007-Q3 2009. Figures for Australia correspond to weekly wages.

Source: World of Work Report 2010 (ILO, 2010a) based on ILO, Crisis database and Global Wage database following national statistical sources.

Countries that tend to exhibit higher wage flexibility also tend to have lower collective bargaining coverage (Table 2). This is indeed observable for the Anglo-Saxon cases, Japan and Republic of Korea, as well as for the new CEE member countries. Of course, while there are a number of factors that explain wage dispersion (technological change, evolving work patterns and non-standard forms of employment, etc.), collective bargaining coverage and minimum wages tend to limit the extent of wage distribution. ${ }^{24}$ This is particularly the case in Belgium, France, the Netherlands and the Scandinavian countries. Only in Austria and Spain does high coverage accompany relatively high wage inequality. In Austria, this can be explained by a tradition of competitiveness-oriented corporatism that allows for some wage flexibility. In Spain, it may reflect the divide in skills distribution, the large share of temporary employment or the trend increase in low-productivity jobs in the construction sector before the crisis (see below). In Germany wage dispersion has grown alongside a decline in collective bargaining coverage, especially in the service sector (and in the absence of a statutory minimum wage). A notable exception to the pattern is Switzerland, where wage dispersion is limited despite rather liberal wage-setting institutions.

\footnotetext{
${ }^{24}$ Already before the onset of the crisis, wages were not growing in line with productivity. See ILO (2008): World of work report 2008: Income inequalities in the age of financial globalization (Geneva, International Institute for Labour Studies).
} 
Table 2. Collective bargaining coverage, wage dispersion and minimum wages in the OECD (mid-2000s)

\begin{tabular}{|c|c|c|c|}
\hline Country & $\begin{array}{c}\text { Collective Bargaining } \\
\text { Coverage }\end{array}$ & Wage Dispersion & $\begin{array}{c}\text { Minimum Wage Relative to } \\
\text { Average Wage }\end{array}$ \\
\hline Australia & 60.0 per cent & 3.31 & 0.52 \\
\hline Austria & 99.0 per cent & 3.37 & - \\
\hline Belgium & 96.0 per cent & 2.43 & 0.51 \\
\hline Canada & 31.5 per cent & 3.75 & 0.42 \\
\hline Czech Rep. & 44.0 per cent & 3.11 & 0.35 \\
\hline Denmark & 82.0 per cent & 2.69 & - \\
\hline Finland & 90.0 per cent & 2.55 & - \\
\hline France & 95.0 per cent & 2.91 & 0.63 \\
\hline Germany & 63.0 per cent & 3.26 & - \\
\hline Hungary & 35.0 per cent & 4.56 & 0.47 \\
\hline Ireland & 66.0 per cent & 3.78 & 0.53 \\
\hline Italy & 80.0 per cent & - & - \\
\hline Japan & 16.1 per cent & 3.06 & 0.35 \\
\hline Korea & 12.0 per cent & 4.74 & 0.39 \\
\hline Netherlands & 82.0 per cent & 2.91 & 0.43 \\
\hline New Zealand & 30.0 per cent & 2.94 & 0.59 \\
\hline Norway & 72.0 per cent & 2.11 & \\
\hline Poland & 35.0 per cent & 4.21 & 0.45 \\
\hline Portugal & 62.0 per cent & - & 0.47 \\
\hline Slovakia & 35.0 per cent & - & 0.43 \\
\hline Spain & 80.0 per cent & 3.53 & 0.45 \\
\hline Sweden & 92.0 per cent & 2.31 & - \\
\hline Switzerland & 48.0 per cent & 2.65 & - \\
\hline United Kingdom & 34.8 per cent & 3.59 & 0.46 \\
\hline USA & 13.5 per cent & 4.85 & 0.34 \\
\hline
\end{tabular}

Source: Amsterdam Institute for Advanced Labour Studies (AIAS) and OECD.

\section{Active and passive labour market policies}

Generally, tax and benefit systems work as automatic stabilisers during economic crises. In particular, the combined effect of unemployment benefits, direct taxes and social security contributions on the stabilisation of income and demand can be simulated in order to assess the extent of automatic stabilisation (Dolls et al, 2009). Assuming a 5 percent unemployment shock, i.e. an increase of the unemployment rate by five percentage points, stabilisation through the tax/benefit system would lead to a stabilisation of more than two thirds in Austria, Denmark and Sweden - with Belgium and Germany following closely (Figure 15). This is both a result of unemployment benefit receipt and a decline in tax receipts. 


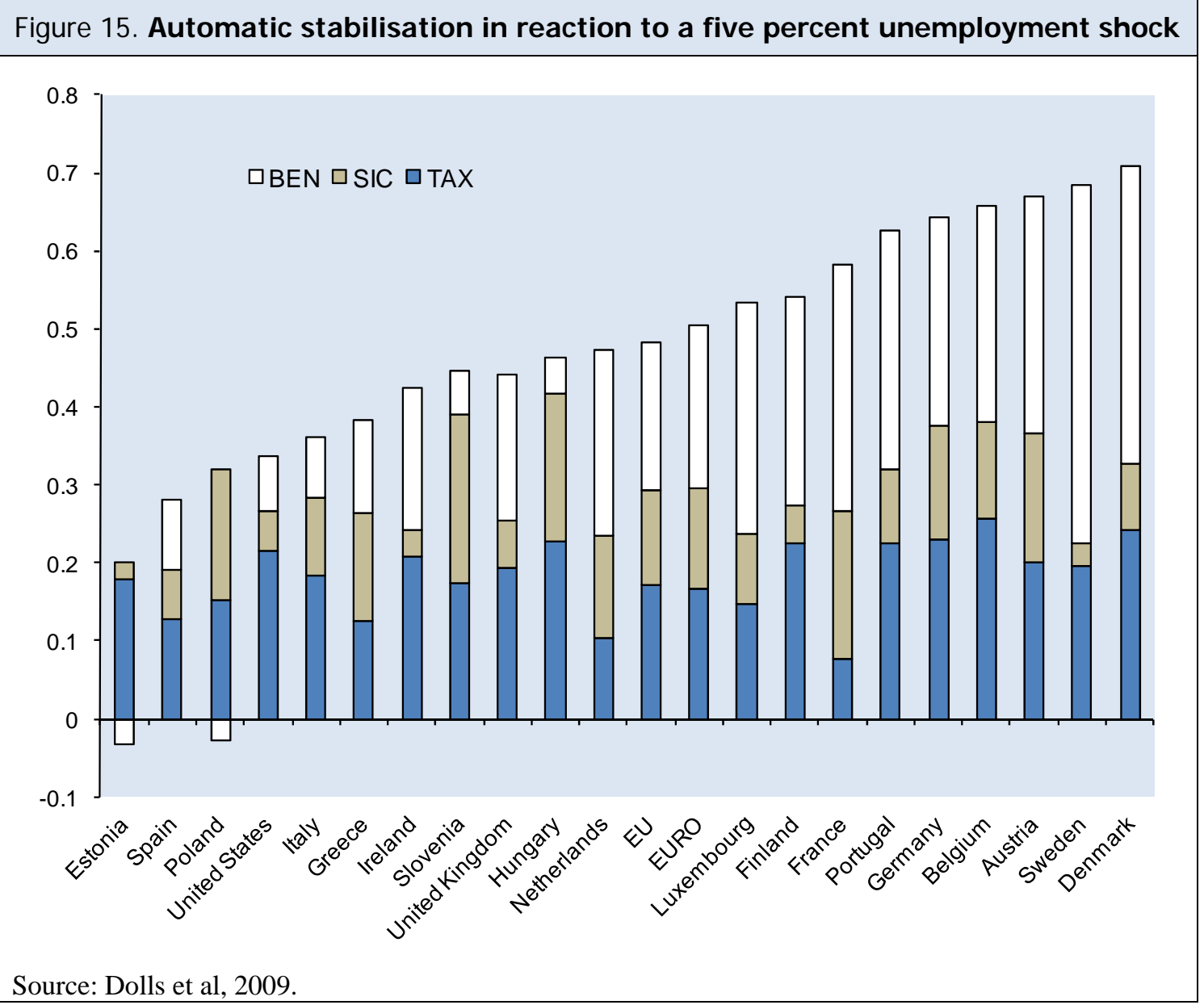

The problem, however, is that unemployment benefits often do not exist in emerging and developing counties. Even in the few cases where unemployment benefit systems do exist, they are often restricted to urban areas, e.g. as is the case in China. For advanced economies, similarly, while many have such schemes in place, there is often a set of criteria for access (e.g. minimum number of hours worked). Consequently, job losers are often not eligible for unemployment benefits. As a result, the share of unemployed receiving benefits varies considerably across countries (Figure 16). ${ }^{25}$

\footnotetext{
${ }^{25}$ See also ILO 2009b: The Financial and Economic Crisis. A Decent Work Response (Geneva, International Institute for Labour Studies).
} 
Figure 16. Share of unemployed receiving benefits in select countries

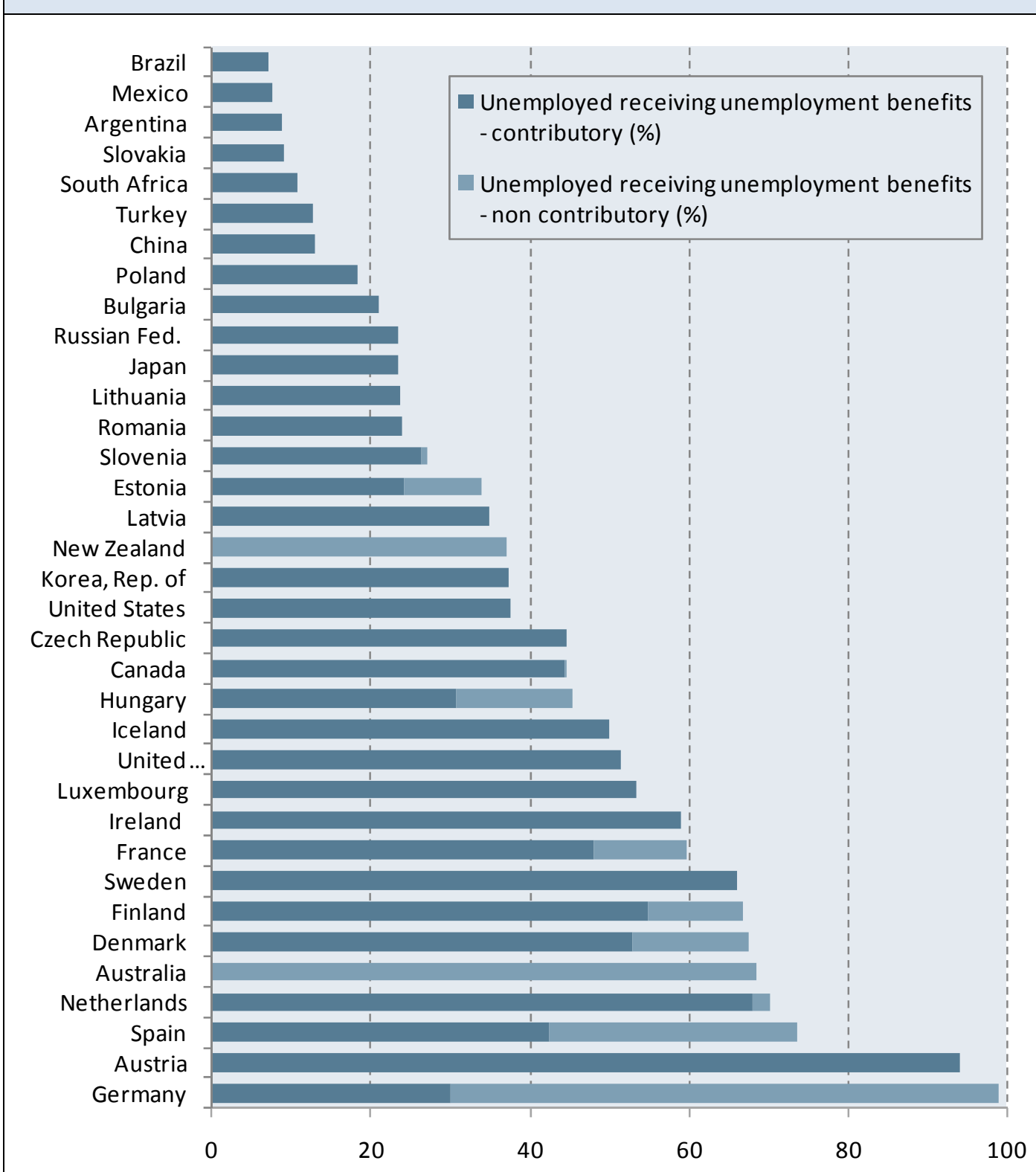

Source: ILO, World Social Security Report 2010: Providing coverage in the time of crisis and beyond. April 2010. Geneva.

Among workers receiving benefits, the level of benefit generosity plays a significant role in terms of supporting worker adjustment (best measured by the OECD's net replacement rates for the first month of unemployment). Both for single average earners and for sole earners in married couples, data for the OECD countries reveals significant differences across countries (Figure 17). Income losses stemming from unemployment are quite small in most continental European countries and most Northern countries. On the other hand, the Mediterranean and the Anglo-Saxon countries provide much lower income replacement. 


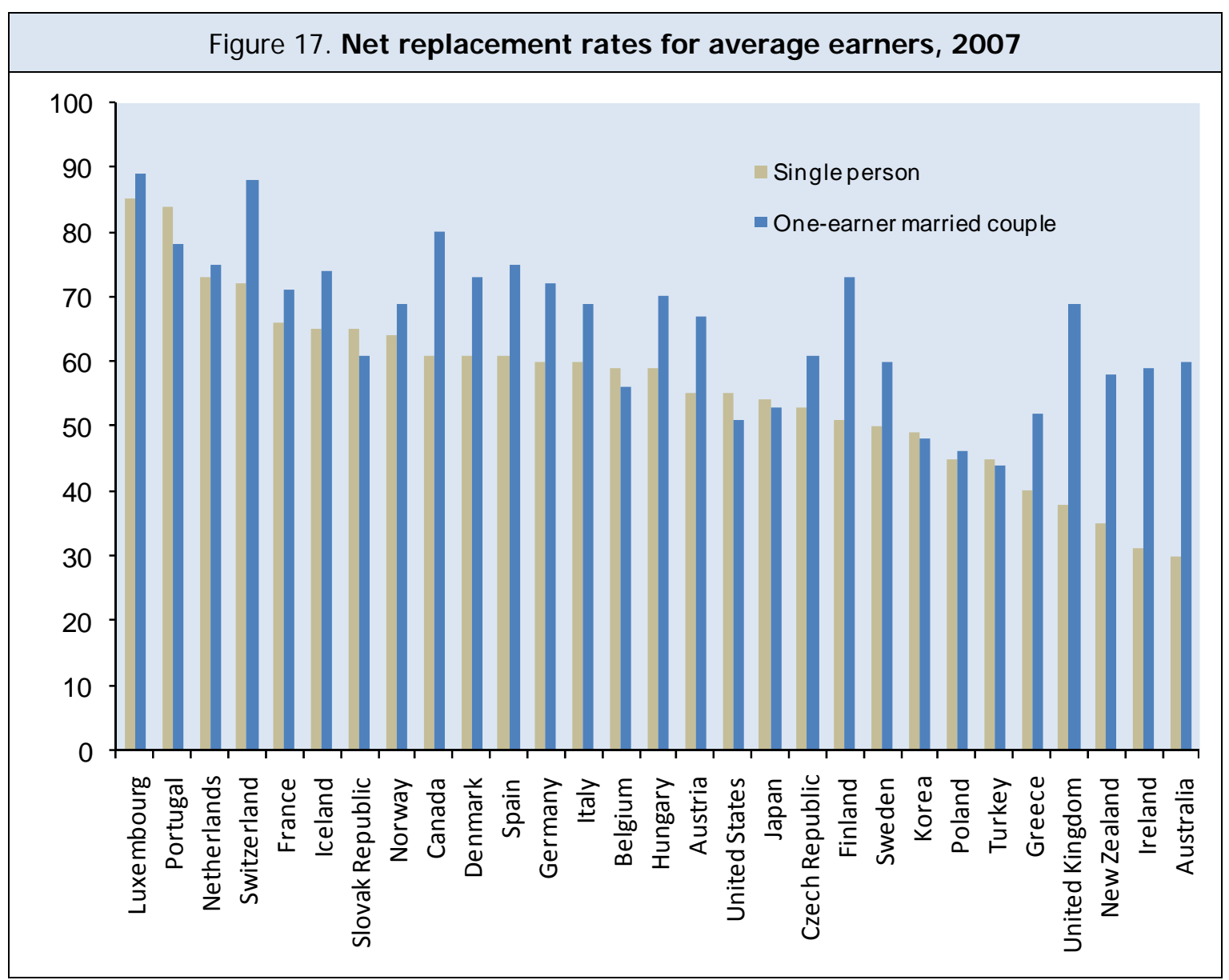

Interestingly, active labour market policies and unemployment benefits as well as short-term work subsidies have been reinforced alongside fiscal stimulus packages. Hence, reintegrating unemployed individuals into the labour market but also providing better income replacement for the unemployed have been major concerns. Given the fact that some groups are more at risk of becoming unemployed than others - and these groups are often less-protected by unemployment insurance (e.g. employees with fixed-term contracts or agency workers), there has been a major tendency to expand unemployment benefits and ease benefit access in particular for these groups. Among a survey of 54 ILO countries, nearly a third extended unemployment benefit coverage or implemented additional social assistance or protection measures. ${ }^{26}$ Similarly, over a quarter introduced partial unemployment benefit schemes with training or part-time work. Among OECD countries, the average annual additional expenditures expected - in discretionary ALMPS - in response to the economic crisis was in some cases substantial (Figure 18).

${ }^{26}$ ILO (2009c): Protecting People Promoting Jobs, ILO Report to the G20 Leader’s Summit, September 2009. 


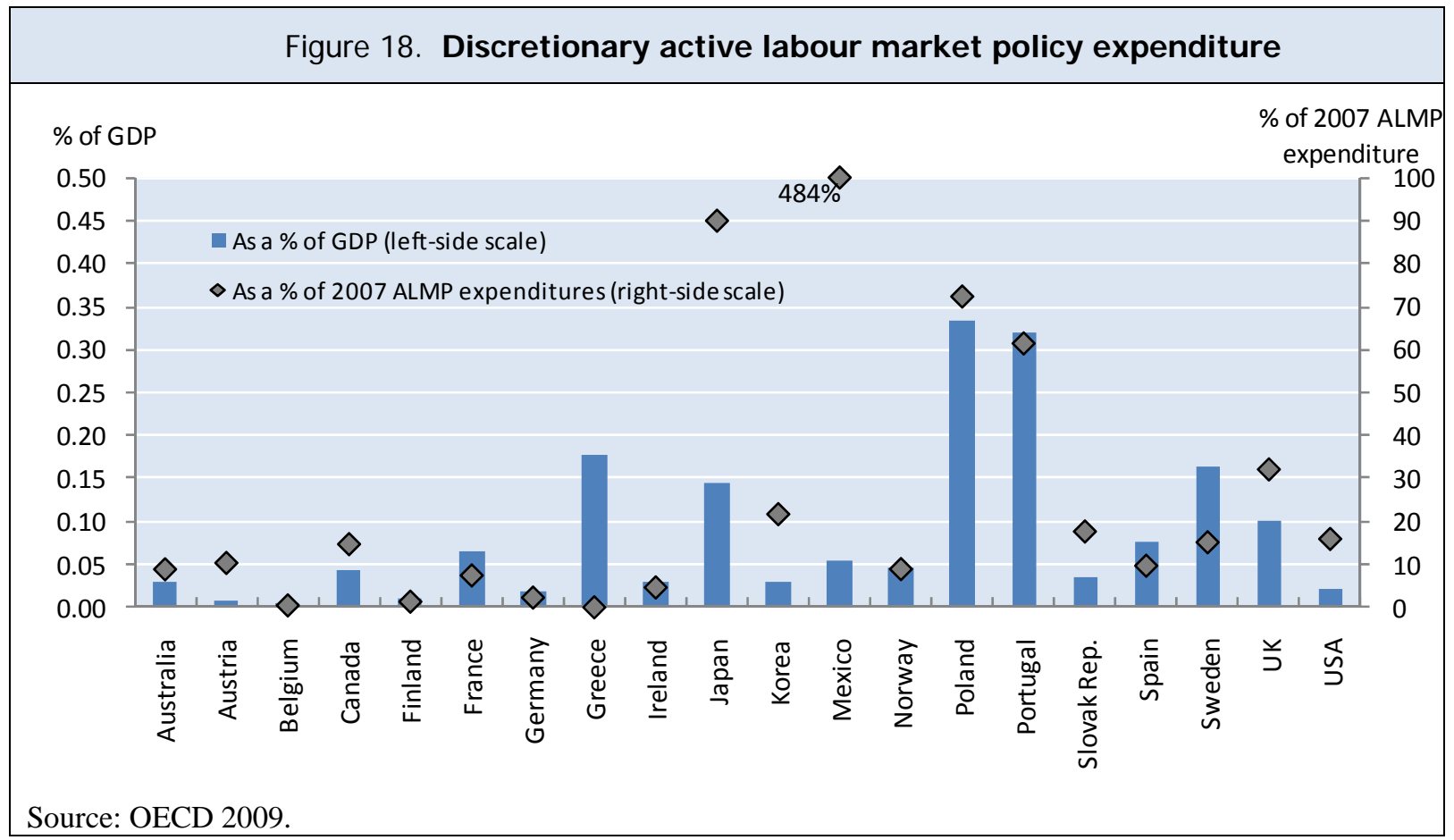

\section{Country case studies}

The following section attempts to explore in more detail - i.e. at the country level - the role internal flexibility in the context of the current crisis. The analysis will focus on the cases of Germany, Denmark, Spain and the United Kingdom.

\section{Germany: Employment stability despite strong export orientation}

Germany is a country which was heavily affected by the steep decline in international trade which, in turn, led to a significant fall in orders and exports especially in core areas of the production model such as machinery and car manufacturing. However, despite its vulnerability due to the dependency on exports and the associated GDP decline of five percent in 2009, unemployment remained stable initially, rising marginally, and employment fell only marginally compared to other countries.

Employment stability is due to a number of factors of course. First, strong growth in major parts of the service sector helped offset losses in export-oriented sectors such as manufacturing and logistics. Second, the relative success of Germany is partly explained by the fact that the core labour market of skilled workers in manufacturing is covered by strong legal dismissal protection - hence, short-term adjustment does not lead to quick layoffs but is dominated by an elaborate arrangement of internal flexibility. Three elements are crucial:

1. Internal flexibility: internal flexibility has already increased considerably over the last two decades both within in the framework of collective bargaining and at the level of the enterprise. Hence, working time can be adjusted flexibly via working time accounts. In fact, while employment was unchanged from mid-2008 to mid-2009, the total volume of hours worked decline by about five percent. At the same time, the social partners also allowed for the adjustment of bargained wages or postponements of wage increases in difficult times. 
2. Concentration of redundancies in the marginal workforce: over the last five years, manufacturing employers increasingly relied on temporary agency staff to establish a flexible segment of the workforce which can be adjusted swiftly under uncertain economic prospects. Therefore, when the crisis began, employers started to reduce the number of agency workers by about 300,000 and thus limited job destruction to this category of workers. At a smaller scale, the same is true for the non-renewal of fixedterm contracts.

3. Heavy reliance on a public short-time work allowance: practices of this nature are embodied in the institutional repertoire of the unemployment insurance and active labour market policy system (Eichhorst and Marx, 2009). The short-time work or partial unemployment scheme was, of course, already in place before the crisis began, but it has been modified in three aspects: (i) the maximum duration for which hours not worked are reimbursed by the unemployment fund at the regular replacement rate applicable in case of unemployment was increased from six to 24 months for inflow in 2009 (18 months in 2010), (ii) for cases of short-time work arising in 2009 and 2010, employers are relieved from social security contributions for hours not worked - regarding employee contributions from the first day of short-time work, regarding employer contributions from the seventh month of reduced working time (or earlier in case of employer-provided training), (iii) administrative requirements for firms entering this scheme were simplified considerably.

Given the abrupt character of the crisis and the uncertainty of its duration, employers have been reluctant to dismiss skilled staff as long as partial unemployment was feasible and a recovery - if partial - expected. In that respect, the internal flexibility mechanisms such as working-time flexibility and complementary short-time work allowances discussed above appear to have been successful in mitigating employment losses. And as exports show some preliminary signs of recovery, the gap may have been sufficiently bridged. At the same time, the marginal workforce has borne the brunt of job losses and most workers have witnessed declines in wages and hours or worked or both.

\section{Denmark}

In the decade before the crisis, Denmark became a celebrated model country for the "flexicurity" approach. The combination of its traditionally flexible labour law, generous unemployment benefits and active labour market policies ensured a rather smooth functioning of the employment model. Thanks to this "golden triangle" the Danish labour market was characterised by high mobility and far above-average employment rates with unemployment virtually non-existent.

However, the recent crisis had a comparatively strong impact on the economy and especially on the labour market with the unemployment rate more than doubling to reach upwards of 7 per cent. One reason for the strong impacts is that the Danish employment system features less internal institutional buffers against an output shock. As one would expect, liberal dismissal regulation contributes to a large inflow into unemployment in an economic crisis. However, labour market recovery should be more dynamic once the economy returns to growth as hiring barriers are lower and activation policies are in place.

Whether this institutional advantage of the Danish model will prove to be beneficial in the near future also depends on the second aspect of the flexicurity concept - social security and activation. The Danish welfare state provides high income replacement in the case of job loss. 
Even after five years of unemployment, net benefits of previous low-wage earners can amount to more than eighty percent. This is the most generous level in the OECD (average: 45 percent). To diminish disincentives to take up work, labour market reforms in previous years have strengthened the activation of unemployed. While active labour market policies were sufficient to promote employment in normal economic times, it remains to be seen how the system will work against the background of severe unemployment. So far, Danish active labour market policies are characterised by policy continuity - also with respect to activation strategies trying to increase labour supply.

The crisis also revealed the macro-economic advantages of a high level of social protection. It can be shown that unemployment insurance had a significant effect as an automatic stabiliser in those countries with sufficient levels of income protection (e.g. vis-à-vis the United States). This holds true for Denmark in particular. Together with Austria and Sweden, the income stabilisation effect of benefits is the largest in the OECD (see Section B above). In a similar fashion the budget available for active measures is tied to the development of the unemployment rate. Therefore, the Danish regime adapts automatically and needs less discretionary intervention by policy makers.

Hence, although the crisis had a severe impact, by supporting incomes the generous Danish welfare state is also helping to support aggregate demand and lessen the overall impact. This is an insight that should be reflected in the reform discussions of countries that traditionally refrain from implementing strong automatic stabilisers. Going forward, the Danish experience has shown that the right mix of welfare state generosity and activation is crucial to reconcile both objectives in times of recovery. While the country has been very successful in the past, the current crisis may require future amendments to strike the right balance.

\section{Spain}

Concerning the international economic crisis, the Spanish labour market is one of the hardesthit in the European Union. The unemployment rate was 20 per cent in April 2010: the highest in over 13 years and double the EU average. The origins of the devastating impact lie partially in its exposure to a vulnerable sector but also in the extent of labour market duality.

The pre-crisis period in Spain was characterised by above-average growth rates, strong job growth and significant reductions in unemployment. Much of the growth stemmed from the strong housing and construction sector but with the onset of the housing price bubble, employment losses were particularly severe in the oversized (in retrospect) sector.

In addition, Spain has relatively flexible job protection regulation at the margin of the labour market. As opposed to strictly regulated permanent contracts, temporary workers form a very flexible tier in the labour market. While this pattern of asymmetric flexibility is by now quite typical for highly regulated European labour markets, Spain in this regard is an extreme case. Before the crisis, approximately one third of all employees worked on a fixed-term contract. Moreover, around 85 percent of all employees working on a temporary contract do so involuntarily with as many as two-thirds holding a contract with a duration of six months or less (twice as high as the EU-15 average)

Much like Germany - although to a greater extent - this segment of highly flexible workers mainly carried the burden of labour market adaptation in the recent recession. Between the beginning of 2007 and the end 2009, the share of temporary workers in total employment 
decreased from 32 to 26 percent - accounting for close to 90 percent of the jobs lost (or more than 1.2 million workers). At the same time, employment among permanent workers has been relatively stable.

Similarly, in an attempt to encourage German-style employment retention, social security payments were lowered for companies that reduced employees' working hours instead of dismissing them. In addition, wage subsidies for workers on short hours and subsidies for companies hiring part-time workers were created. Hence, Spanish policy makers tried to stimulate policies in favour of working time and therefore internal flexibility which is seen as a better alternative to excessive external flexibility stemming from fixed-term contracts. At the same time, policy makers also extended unemployment benefits. However, unlike Germany, the experience of Spain has been unsuccessful.

A possible reason for the failure of this programme to prevent unemployment from rising continuously may be in the characteristics of the laid-off workers. The jobs that were created in the upswing preceding the crisis and which were subsequently lost were predominantly low-productivity jobs in construction. The lack of success may have much to do with the absence of skill-oriented internal flexibility - as is the case in the German manufacturing sector adjustment.

Hence, there are deeper-rooted challenges for the Spanish employment model: to shift jobcreation to sectors with higher productivity and to overcome segmentation in the labour market. Concerning the latter, the lessons of the crisis do not seem to have increased chances for reform. While there has been an expansion of unemployment benefits to counter social concerns, liberalisation of dismissal laws still ranks low on the agenda.

\section{United Kingdom}

The United Kingdom was also heavily hit by the current crisis - but in contrast to Spain and Germany, the British economy was hit initially by virtue of its role as Europe's financial centre, which had benefited from a dynamic development of the banking sector and strong housing price growth for many years (Bell and Blanchflower 2009). This has been associated with a dynamic development of job creation in the private service sector. High exposure to global financial business and, at the same time, a quite flexible labour market and a smaller welfare state - compared to most Continental European countries - imply a high vulnerability of the labour market. Compared with, for example, Germany, external flexibility is more dominant than internal adjustment of firms. In accordance with a pattern dominated by external flexibility, working time adjustment did not contribute significantly to the adjustment process following the recent shock. More flexibility is thus observed with respect to wages in the private sector.

In good times, a less-regulated labour market can contribute to strong employment growth; in bad times this reduces the buffering effect of intra-organisational arrangements. At the same time, the tax/benefit system in the United Kingdom provides less automatic stabilisation than Continental European or Scandinavian countries. While the increase in unemployment was stronger in the United Kingdom than it was in Germany, it was less in comparison to Denmark, Spain or the United States. A more in-depth analysis shows that, at least until recently, job losses in the private sector were compensated for by a stable and still-expanding public sector. Major job cuts could be observed in the vulnerable exposed sectors such as manufacturing, finance and construction, as well as distributional services. 
Given the limited role of automatic stabilisation and the size of the shock experienced by the British economy, it is interesting to see that the United Kingdom adopted a larger-thanaverage fiscal stimulus package which helped mitigate the immediate labour market impact of the crisis but is now contributing to pressures to reduce fiscal deficits and debt. At the same time, the United Kingdom is also one of the countries which implemented the most comprehensive crisis-related reforms in the realm of unemployment protection and active labour market policies. Here, the existing institutional repertoire was expanded in order to cope with increasing unemployment and speed up reintegration into employment. Discretionary policy-making complemented active labour market instruments which were already in place at the outset of the current crisis such as the JobCentre Plus and Rapid Response Services to achieve a broader activation with more intensive support for all jobseekers out of work for more than six months, an activation guarantee for young people and a more general scheme implemented in fall 2009 ('Flexible New Deal') replacing earlier, more selective ones. Furthermore, incentives for employers which recruit and train people who have been unemployed for at least six months were introduced and extra funding was given for training, not only for unemployed people but also for start-up support.

\section{Conclusions}

The labour market impact of the current crisis has varied considerably across countries irrespective of the GDP loss. Certainly, the magnitude, the timing and the composition of stimulus efforts have helped to mitigate the effects. Similarly, the structure of the economy and exposure to certain vulnerable sectors, e.g. construction, has in some case exacerbated job loss. The purpose of this study, however, is to shed light on the extent to which preexisting institutional arrangements, in combination with labour market related policies, can explain some of the variation in labour market performance.

Early indications are that countries that could rely on strong internal flexibility were better able to control employment losses and rising unemployment. This was achieved by protecting the core labour market through relatively strict employment protection and making labour market adjustments via working hours (and wages) rather than through layoffs. For example, in Germany working time accounts and complementary short-time work allowances helped stabilise the manufacturing sector with adjustments in employment occurring at the margins.

However, such schemes have important distributional consequences, i.e. non-standard workers have borne the brunt of employment losses, deepening labour market dualization. This is particularly apparent in the case of Spain where the termination of temporary contracts is a major channel of adjustment. Non-standard workers not only face a higher risk of unemployment, they also tend to be less well protected in terms of access to labour market support such as unemployment insurance. In the case of Spain, they also tend to less well equipped to take up new jobs. As a result, non-standard workers are disadvantaged twice: first, in terms of employment stability, and second, in terms of access to adequate social benefits and active labour market support.

There is an urgent need to move towards more equal distribution of risks and benefits. In this respect, the role of automatic stabilisers such as unemployment benefits merits special attention. They provide much needed income and labour market support (e.g. training) at the individual level with important implications for aggregate demand. These need to be made 
available to a wider group of workers and not just the core labour force. Moreover, automatic stabilisers are also just that - automatic - and therefore easier and more efficient to implement than discretionary measures which tend to create greater challenges in terms of appropriate implementation and often can only become effective after a certain time lag. Indeed, many policy initiatives during the crisis illustrate that discretionary changes in social and labour market policies were tied to existing programmes (e.g. expansion of short-time work, more generous unemployment benefits or hiring subsidies, more training or job search assistance) rather than introducing completely new elements.

In sum, keeping unemployment low by means of internal flexibility and complementary public support via automatic or discretionary policy interventions has shown some early signs of success - at least in the short term and in spite of the magnitude of the crisis. However, as the recovery begins to take hold, there are important implications for structural adjustment as this will require a different policy approach. In particular, rather than one grounded in bridging the temporary loss of demand by subsidising sectors that may be in decline, action will be needed to stimulate economic innovation and labour market mobility. This means promoting external flexibility and job reallocation and encouraging internal functional flexibility through lifelong learning and workplace-related training. Here the role of effective active labour market policies, i.e. job search assistance and training as well as on hiring subsidies and start-up grants will be essential to encouraging quick and sustainable reemployment. For the moment, however, the employment recovery is fragile at best. In many instances, employment continues to fall and therefore crisis-related stabilisation measures are still needed and if properly designed can help to encourage an overall recovery while mindful (and supportive) of fiscal considerations. 


\section{Bibliography}

Albaek, K.; Sorensen, B.E. 1998. "Worker flows and job flows in Danish manufacturing, 1980-91”, in Economic Journal, Vol. 108, No. 451, pp. 1750-1771.

Baker, D. et al. 2007. "Are protective labor market institutions really at the root of unemployment? A critical review of the evidence” in Capitalism and Society, Vol. 2, No. 1.

Bassanini, A.; Duval, R. 2006. Employment patterns in OECD countries: Reassessing the role of policies and institutions (Paris OECD).

Bertola, G.; Rogerson, R. 1997. “Institutions and labor reallocation”, in European Economic Review, Vol. 41, No. 6, pp. 1147-1171.

Blanchard, O.; Wolfers, J. 2000. "The role of shocks and institutions in the rise of European unemployment: The aggregate evidence," in The Economic Journal, Vol. 110, No. 462, pages C1-33.

Cazes, S. and Tonin, M. Forthcoming. "Employment protection legislation and job stability: A European cross-country analysis”, in International Labour Review, Vol. 149 (2010), No. 3.

Daly, M.; Hobijn, B.; Kwok, J. 2009. “Jobless recovery redux?”, in Economic Letter, No. 18 (San Francisco, CA, Federal Reserve Bank of San Francisco).

Eichhorst, W.; Feil, M.; Braun, C. 2008. What have we learned? Assessing labor market institutions and indicators, IZA Discussion Paper No. 3470, Institute for the Study of Labor (Bonn, IZA).

Elsby, M.; Hobijn, B.; Sahin, A. 2008. Unemployment dynamics in the OECD, Working Paper No. 14617, National Bureau of Economic Research (NBER, Washington, DC).

Escudero, V. 2009. Effects of the crisis on the financial sector: Trends and policy issues, Discussion Paper No. 197 (Geneva, International Institute for Labour Studies, ILO).

Estevez-Abe, M.; Iversen, T.; Soskice, D. 2001. "Social protection and the formation of skills: A reinterpretation of the welfare state”, in P.A. Hall; D. Soskice (eds.): Varieties of capitalism: The institutional foundations of comparative advantage (Oxford, Oxford University Press).

European Commission. 2009. EU employment situation and social outlook, DG Employment, Social Affairs and Equal Opportunities (Brussels).

Freynes, B. P. Forthcoming. "Measuring firing costs: The case for direct methods", in International Labour Review, forthcoming.

Hall, P.A.; Soskice, D. (eds). 2001. Varieties of capitalism: The institutional foundations of comparative advantage (Oxford, Oxford University Press). 
Horton, K.M.; Manmohan, K.; Paolo, M. 2009. The state of public finances: A crosscountry fiscal monitor, IMF Staff Position Note (IMF, Washington DC).

International Labour Organization (ILO). 2010a.World of work report 2010: From one crisis to the next? (Geneva, International Institute for Labour Studies). .

-2010b. World Social Security Report 2010: Providing coverage in the time of crisis and beyond (Geneva, April 2010)

-2009a. World of work report 2009: The Global Jobs Crisis and Beyond (Geneva, International Institute for Labour Studies).

-2009b. The Financial and Economic Crisis: A Decent Work Response (Geneva, International Institute for Labour Studies).

-2009c. Protecting people promoting jobs: A survey of country employment and social protection policy responses to the global economic crisis, ILO report to the G20 Leaders’ Summit, Pittsburgh, 24-25 Sep

-2008. World of work report 2008: Income inequalities in the age of financial globalization (Geneva, International Institute for Labour Studies).

International Monetary Fund (IMF). 2010. World Economic Outlook: Rebalancing growth, April (Washington, DC).

Layard R.; Nickell, S.; Jackman, R. 2005. Unemployment: Macroeconomic performance and the labour market (Oxford, Oxford University Press)

Organisation for Economic Co-operation and Development (OECD). 2009. Economic outlook, No. 86 (Paris, December).

Petrongolo, B.; Pissarides, C.A. 2008. “The ins and outs of European unemployment”, in American Economic Review, Vol. 98, No. 2, pp. 256-262.

Pissarides, C.A. 1986. “Unemployment and vacancies in Britain”, in Economic Policy, Vol. 1, No. 3, pp. 499-541.

Tasci, M.; Fee, K. 2009. The incidence and duration of unemployment over the business cycle (Cleveland, OH, Federal Reserve Bank of Cleveland).

United Nations. 2009. LINK global economic outlook, presented at the UN Department of Economic and Social Affairs Expert Group Meeting on the World Economy (Project LINK), St. Petersburg, 4-6 June.

Venn, D. 2009. Legislation, collective bargaining and enforcement: Updating the OECD employment protection indicators, OECD Social, Employment and Migration Working Papers No. 89 (Paris, OECD). 